\title{
Nickel-Mediated Cross-Coupling of Boronic Acids and Phthalimides for the Synthesis of Ortho-Substituted Benzamides
}

\author{
Ethan M. Heyboer, Rebecca L. Johnson, Megan R. Kwiatkowski, \\ Trey C. Pankratz, Mason D. Yoder, Kimberly S. DeGlopper, Grace C. \\ Ahlgrim, Joseph M. Dennis, and Jeffrey B. Johnson* \\ Department of Chemistry, Hope College, Holland, MI 49423 \\ jjohnson@hope.edu
}

Supporting Information

Index

Optimization $\quad$ S2

Attempts at Catalysis - Ligand Screen S4

$\begin{array}{ll}\text { NMR Spectra } & \text { S7 }\end{array}$ 


\section{Optimization Efforts}

Table S1. Examination of Solvents<smiles>CCOC(=O)c1ccc(N2C(=O)c3ccccc3C2=O)cc1</smiles>

\begin{tabular}{|c|c|c|c|}
\hline Entry & Solvent & Temperature $\left({ }^{\circ} \mathrm{C}\right)$ & $\begin{array}{l}\text { Crude Yield } \\
(\%) \text { of } 2^{b}\end{array}$ \\
\hline 1 & THF & 55 & 90 \\
\hline 2 & Dioxane & 100 & 60 \\
\hline 3 & DME & 75 & 50 \\
\hline 4 & Toluene & 100 & 45 \\
\hline 5 & $\mathrm{DMF}$ & 100 & $<5$ \\
\hline 6 & Acetonitrile & 80 & $<5$ \\
\hline 7 & DMSO & 100 & 54 \\
\hline 8 & $\mathrm{CH}_{2} \mathrm{Cl}_{2}$ & 40 & $<5$ \\
\hline 9 & 2-MeTHF & 80 & 78 \\
\hline
\end{tabular}

Table S2. Additional reaction optimization<smiles>CCOC(=O)c1ccc(N2C(=O)c3ccccc3C2=O)cc1</smiles><smiles>CCOC(=O)c1ccc(NC(=O)c2ccccc2-c2ccccc2)cc1</smiles>

\begin{tabular}{llc}
\hline Entry & Change from Standard Conditions $^{\boldsymbol{a}}$ & $\begin{array}{l}\text { Crude Yield }^{(\%)} \text { of }^{\boldsymbol{b}} \\
(\mathbf{0}\end{array}$ \\
\hline 1 & None & 90 \\
2 & Phenyl boronic acid pinacol ester & $<5$ \\
3 & Phenyl boronic acid (1.0 equiv) & 62 \\
4 & Phenyl boronic acid (1.5 equiv) & 78 \\
3 & Potassium phenyltrifluoroborate & $<5$ \\
4 & No bipy & $<5$
\end{tabular}




\begin{tabular}{|c|c|c|}
\hline 5 & $\mathrm{PPh}_{3}(2.2$ equiv) instead of bipy & $<5$ \\
\hline 6 & $\mathrm{P}(\text { furyl })_{3}(2.2$ equiv) instead of bipy & $<5$ \\
\hline 7 & 1,10-phenanthroline instead of bipy & 45 \\
\hline 8 & $\begin{array}{l}\text { 1,2-diphenylphosphinoethane instead of } \\
\text { bipy }\end{array}$ & 12 \\
\hline 9 & 0.2 equiv $\mathrm{Ni}(\mathrm{COD})$ and 0.22 equiv bipy & 19 \\
\hline 10 & No $\mathrm{Ni}(\mathrm{COD})_{2}$ & $<5$ \\
\hline 11 & $\mathrm{Ni}(\text { acac })_{2}$ instead of $\mathrm{Ni}(\mathrm{COD})_{2}$ & $<5$ \\
\hline 12 & $\mathrm{Ni}(\mathrm{acac})_{2}$ with $\mathrm{Mn}^{0}$ instead of $\mathrm{Ni}(\mathrm{COD})_{2}$ & $<5$ \\
\hline
\end{tabular}

\section{Table S3. Examination of Additives}<smiles>CCOC(=O)c1ccc(NC(=O)c2ccccc2-c2ccccc2)cc1</smiles>

\begin{tabular}{lll}
\hline Entry & Additive & $\begin{array}{l}\text { Crude Yield } \\
\text { (\%) of } \mathbf{2}^{\boldsymbol{b}}\end{array}$ \\
\hline 1 & none & 55 \\
2 & $\mathrm{~K}_{2} \mathrm{CO}_{3}$ (2.2 equiv) & 90 \\
3 & $\mathrm{~K}_{2} \mathrm{CO}_{3}$ (1 equiv) & 74 \\
4 & $\mathrm{CaCl}_{2}$ (2 equiv) & 34 \\
5 & $\mathrm{NaI}^{2}$ equiv) & $<5$ \\
6 & $\mathrm{Cs}_{2} \mathrm{CO}_{3}$ (1 equiv) & 61 \\
7 & $\mathrm{NaBH}_{4}$ (1 equiv) & 16 \\
8 & $\mathrm{MgSO}_{4}$ (2 equiv) & 58 \\
9 & $\mathrm{~K}_{2} \mathrm{CO}_{3}$ (2 equiv) + & 78 \\
& $\mathrm{MgSO}_{4}$ (2 equiv) \\
\hline
\end{tabular}

a) Conditions: 1 ( $0.5 \mathrm{mmol}, 1.0$ equiv), $\mathrm{Ni}(\mathrm{COD})_{2}$ (1.0 equiv), bipyridine (1.1 equiv), phenyl boronic acid (2.0 equiv), and additive in THF $(2.0 \mathrm{~mL})$ at $55^{\circ} \mathrm{C}$ under an inert atmosphere. b) Determined by GC/MS or ${ }^{1} \mathrm{H}$ NMR. 
Figure S1. NHC precursors used in optimization studies

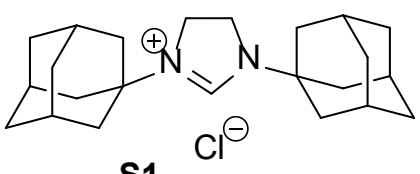

S1
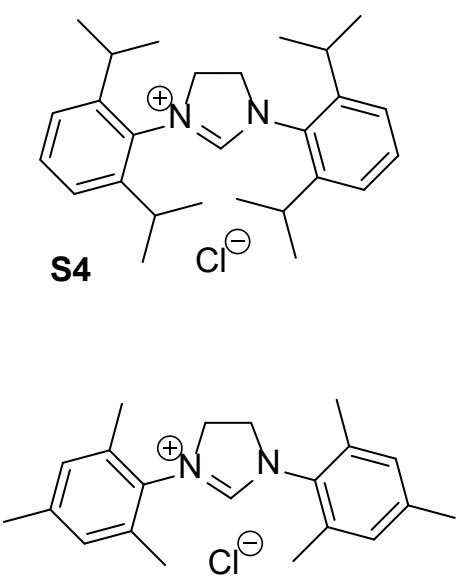

S7

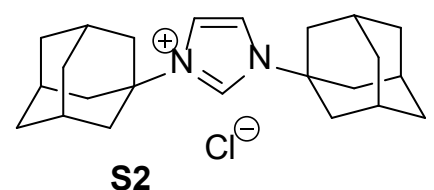

S2
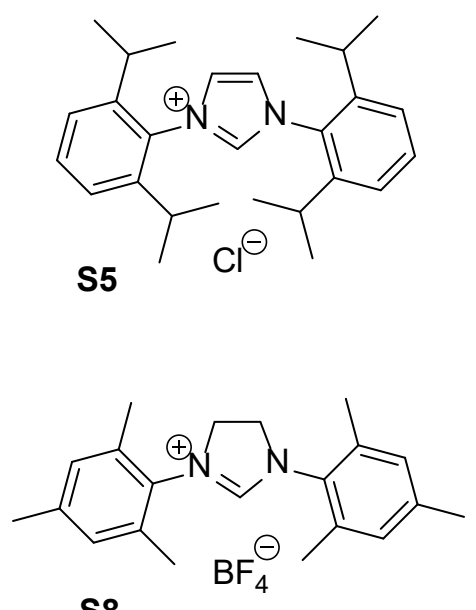

S8

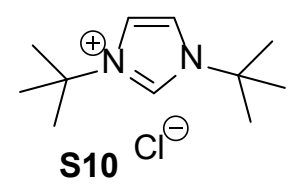

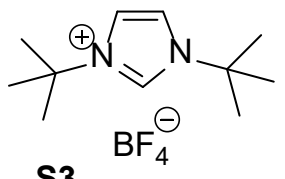

S3
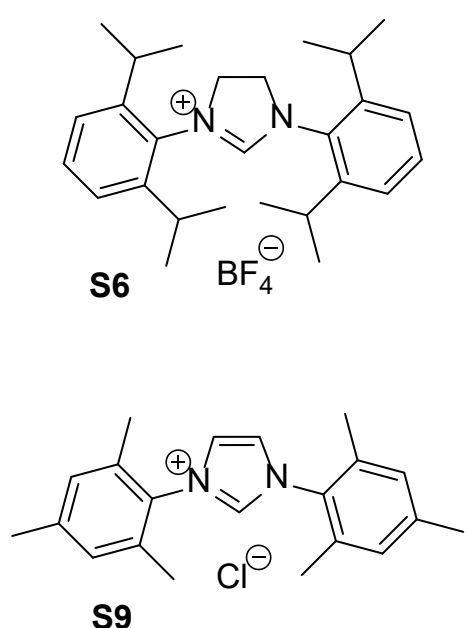
Table S4. Exploration of NHC ligands under catalytic conditions

\begin{tabular}{lllll} 
& & & \\
\hline
\end{tabular}


Table S5. Additional Attempts at Catalysis

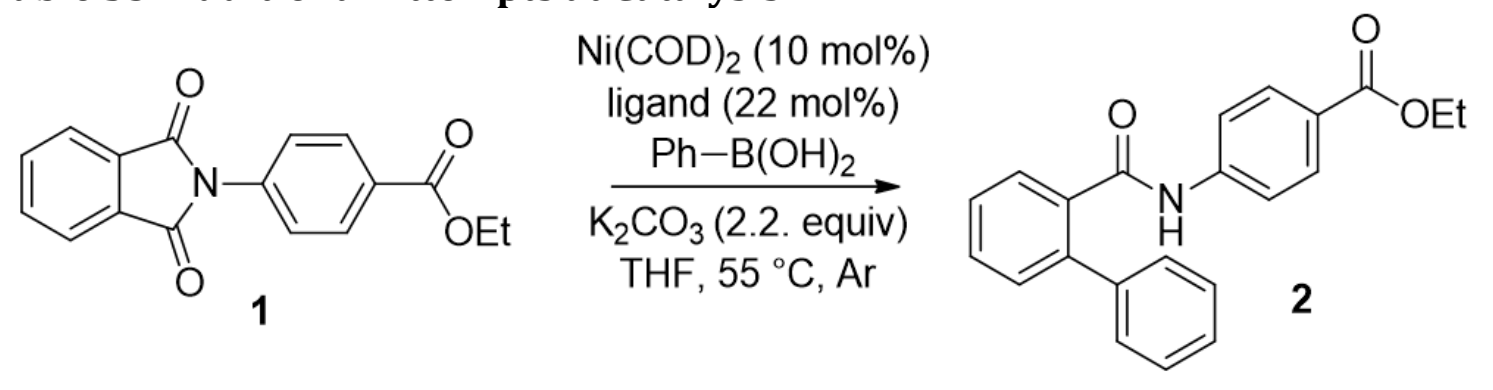

\begin{tabular}{|c|c|c|}
\hline Entry & Change from Standard Conditions ${ }^{a}$ & $\begin{array}{l}\text { Crude Yield } \\
(\%) \text { of } 2^{b}\end{array}$ \\
\hline 1 & None & 19 \\
\hline 2 & DMSO at $130^{\circ} \mathrm{C}$ & 28 \\
\hline 3 & Addition of 1.1 equiv IBX & 9 \\
\hline 4 & Addition of 1.1 equiv pyridine $N$-oxide & 14 \\
\hline 5 & Use of $N-\mathrm{C}_{6} \mathrm{~F}_{5}$ substituted imide & 8 \\
\hline 6 & Addition of 1.1 equiv $\mathrm{NaI}$ & $<5$ \\
\hline 7 & 48 hour reaction time & 18 \\
\hline 8 & 72 hour reaction time & 17 \\
\hline
\end{tabular}


${ }^{1} \mathrm{H}$ and ${ }^{13} \mathrm{C}$ NMR spectra for $\mathbf{2}$
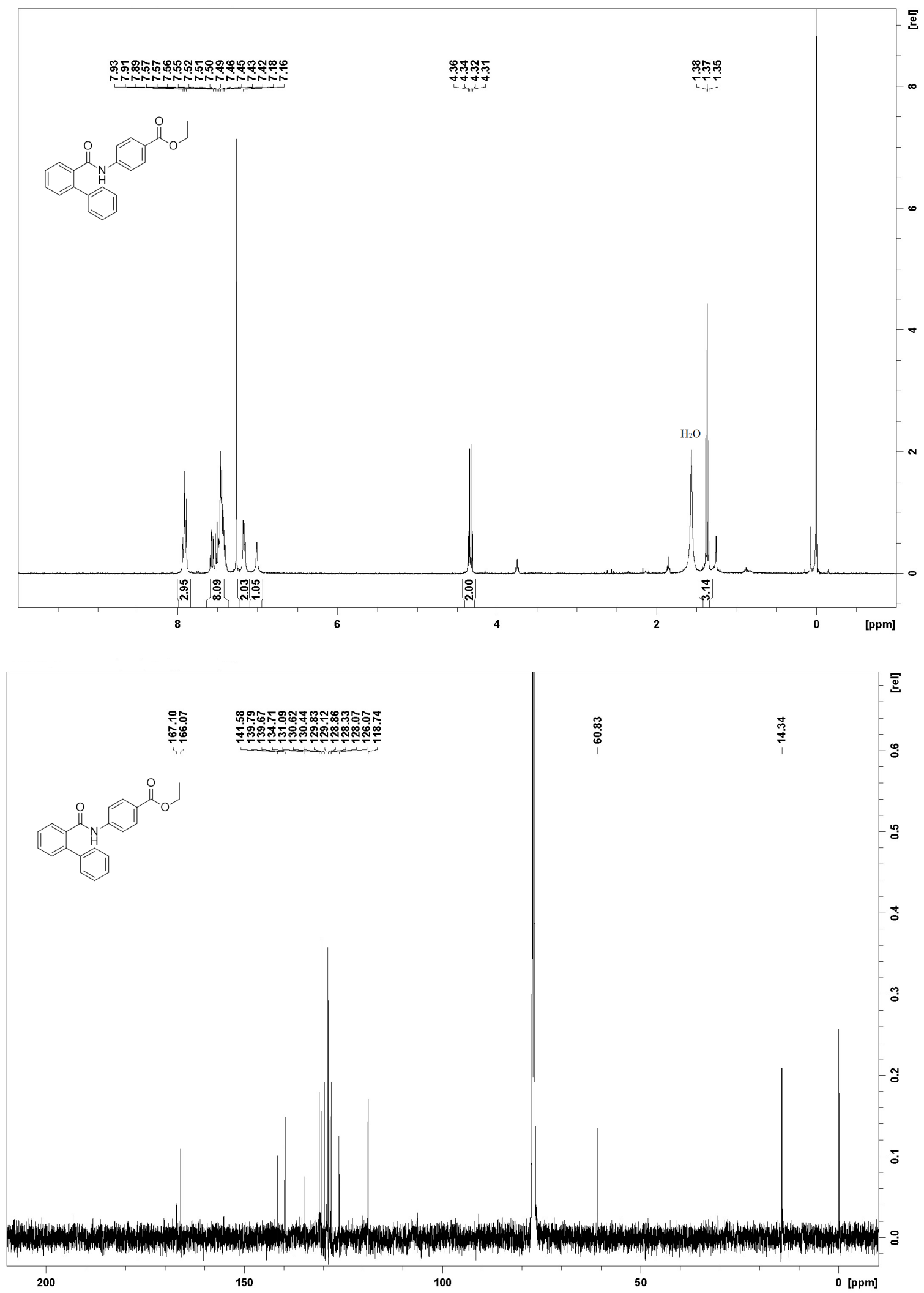
${ }^{1} \mathrm{H}$ and ${ }^{13} \mathrm{C}$ NMR spectra for 4
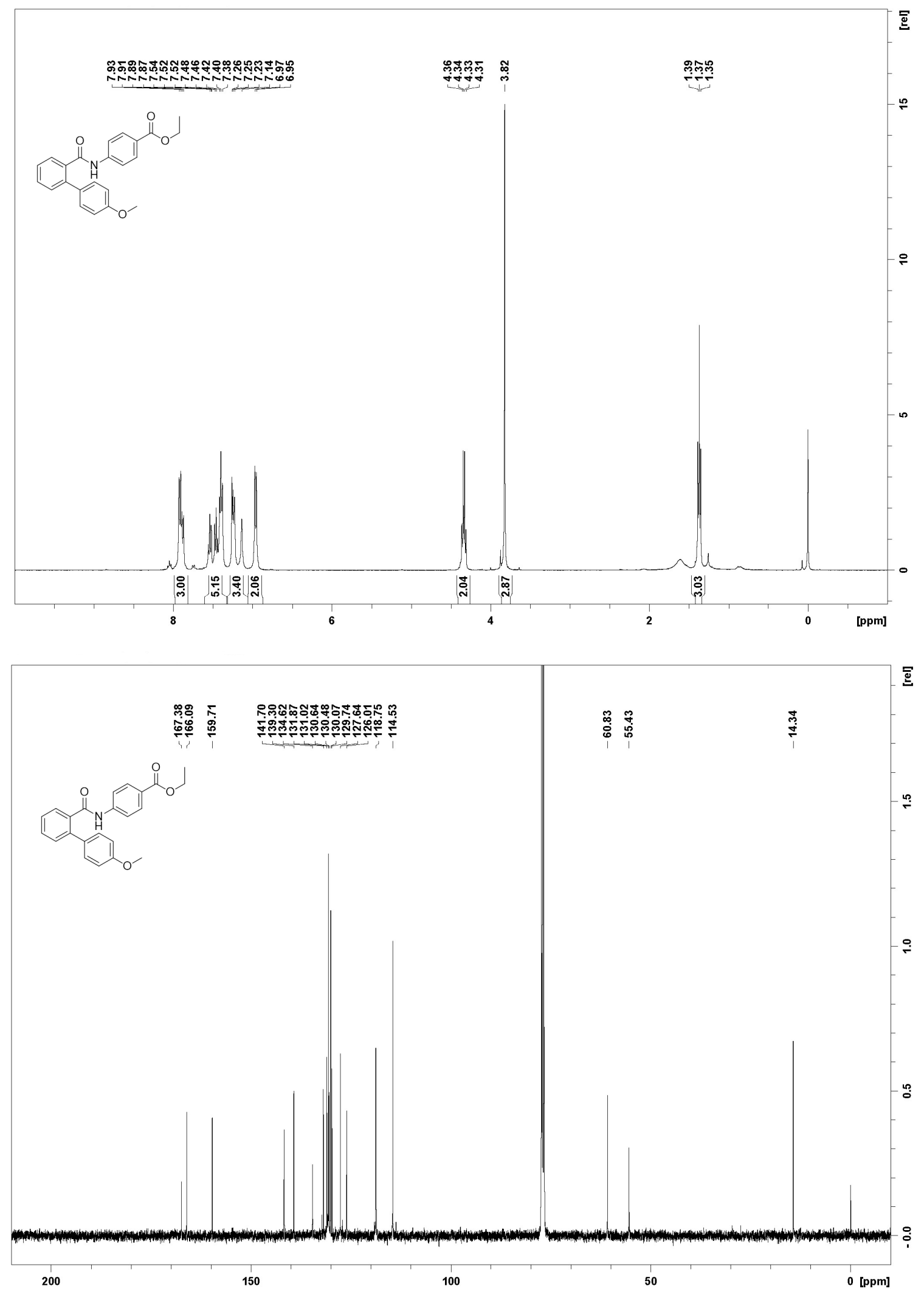
${ }^{1} \mathrm{H}$ and ${ }^{13} \mathrm{C}$ NMR spectra for $\mathbf{5}$

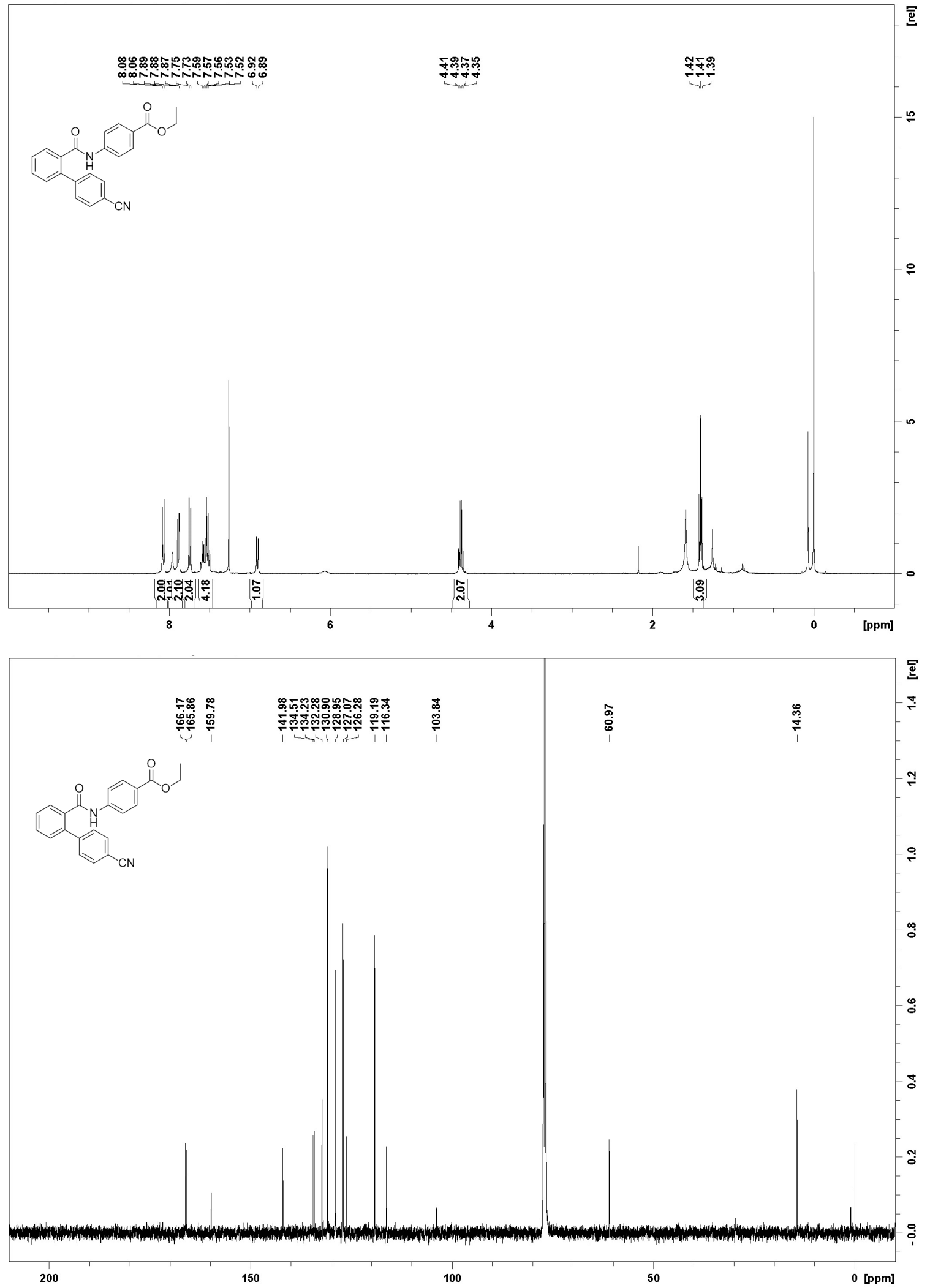


${ }^{1} \mathrm{H}$ and ${ }^{13} \mathrm{C}$ NMR spectra for 6

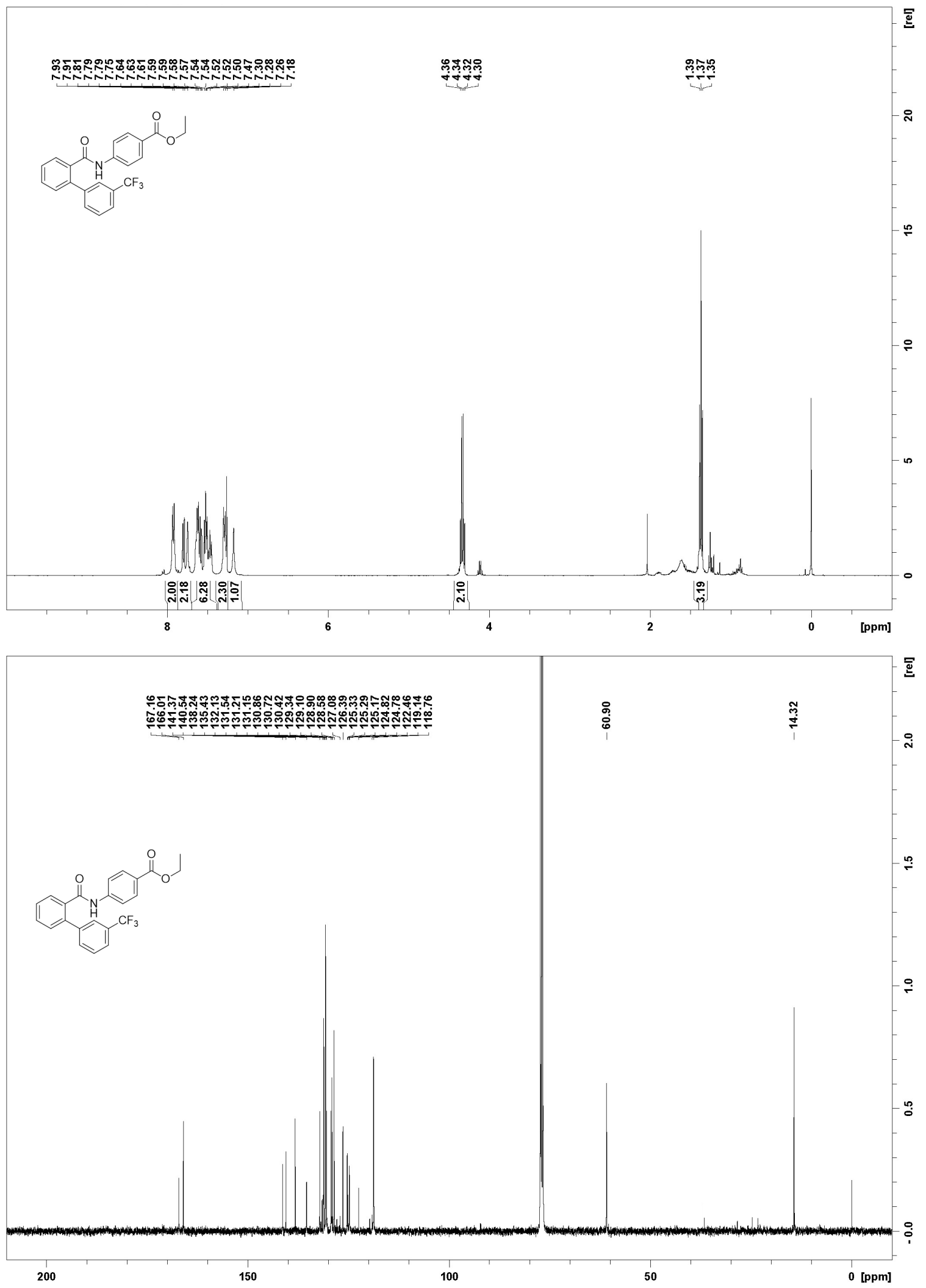


${ }^{1} \mathrm{H}$ and ${ }^{13} \mathrm{C}$ NMR spectra for 7

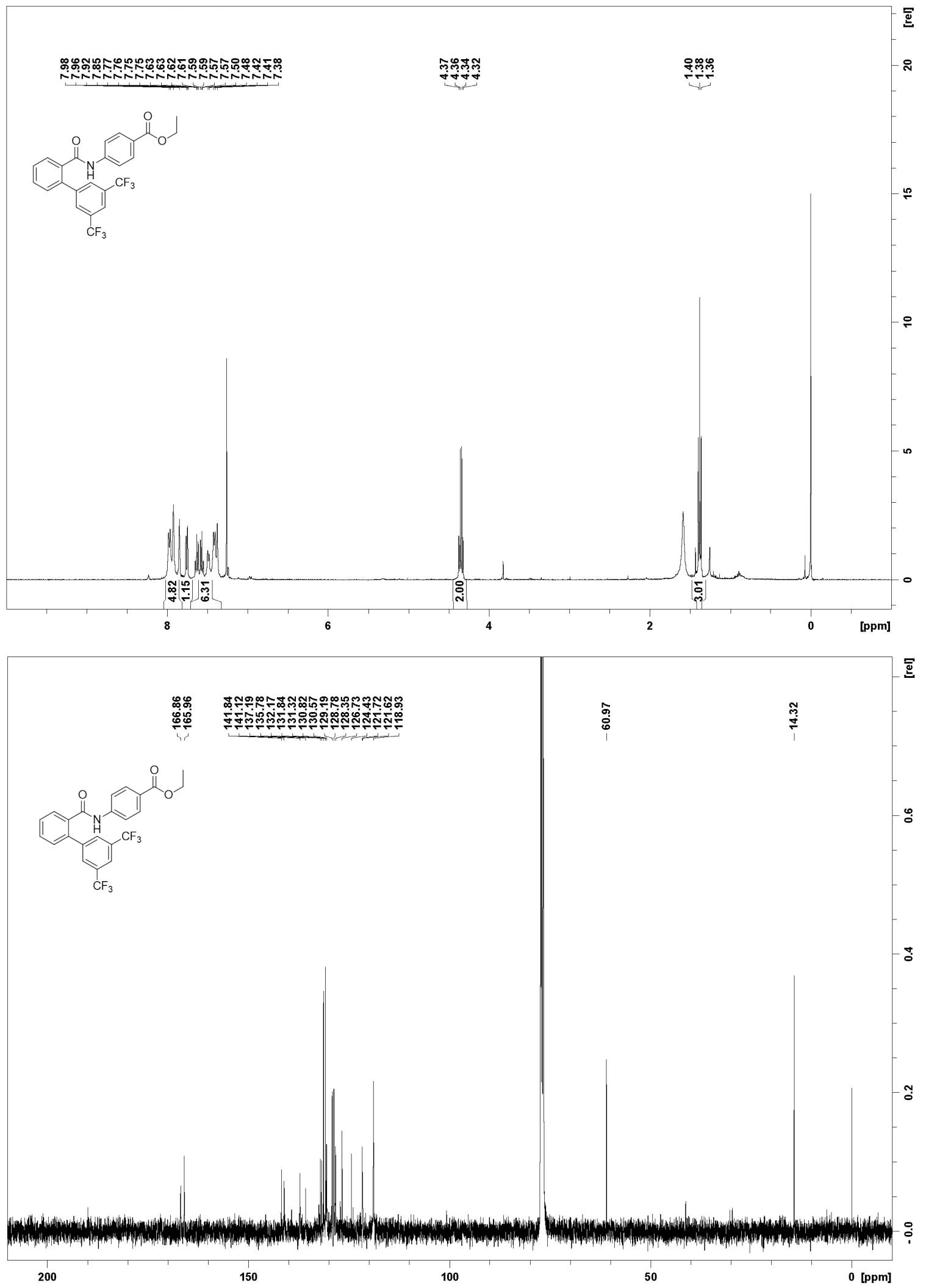


${ }^{1} \mathrm{H}$ and ${ }^{13} \mathrm{C}$ NMR spectra for 8

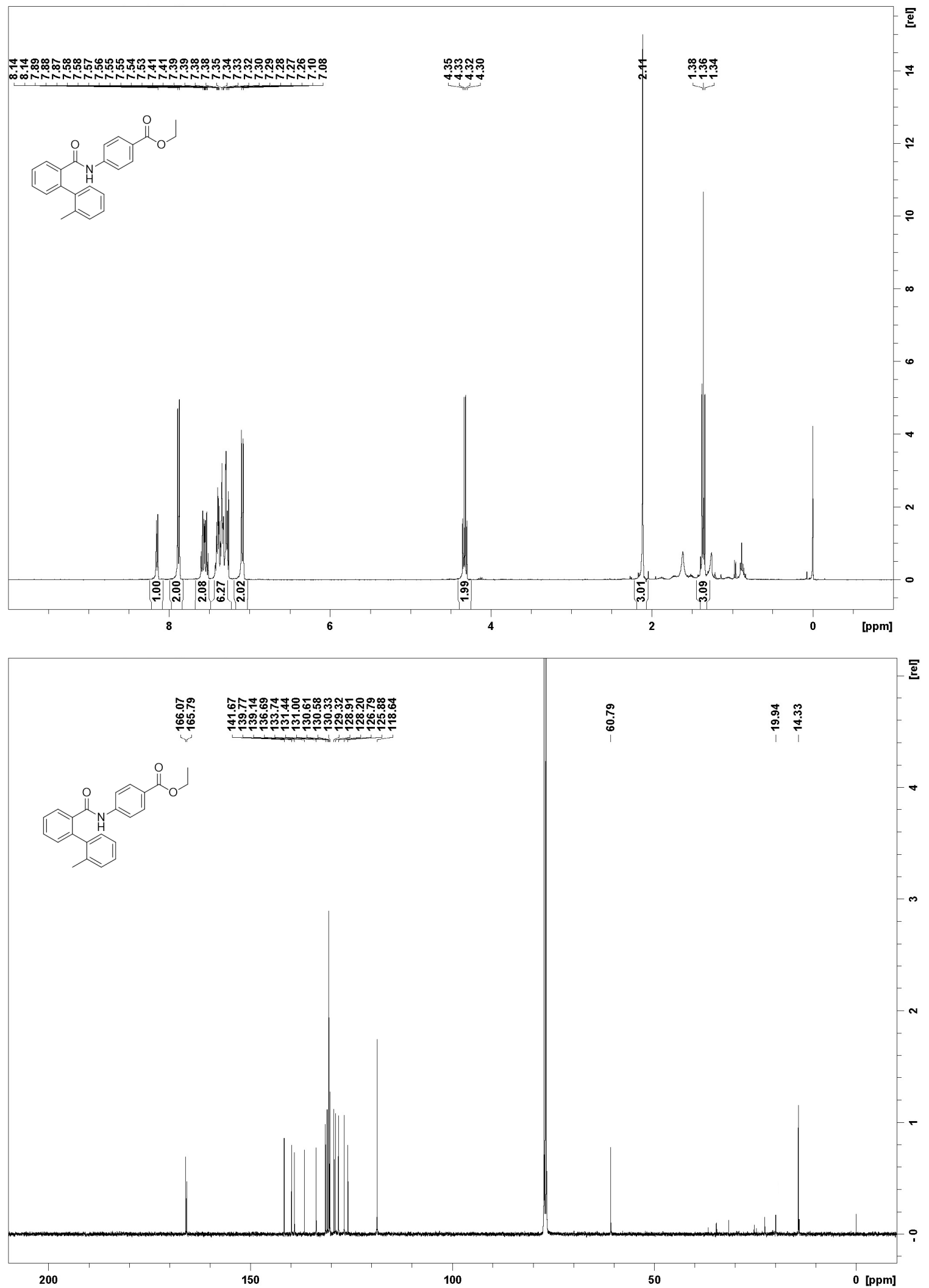


${ }^{1} \mathrm{H}$ and ${ }^{13} \mathrm{C}$ NMR spectra for 9

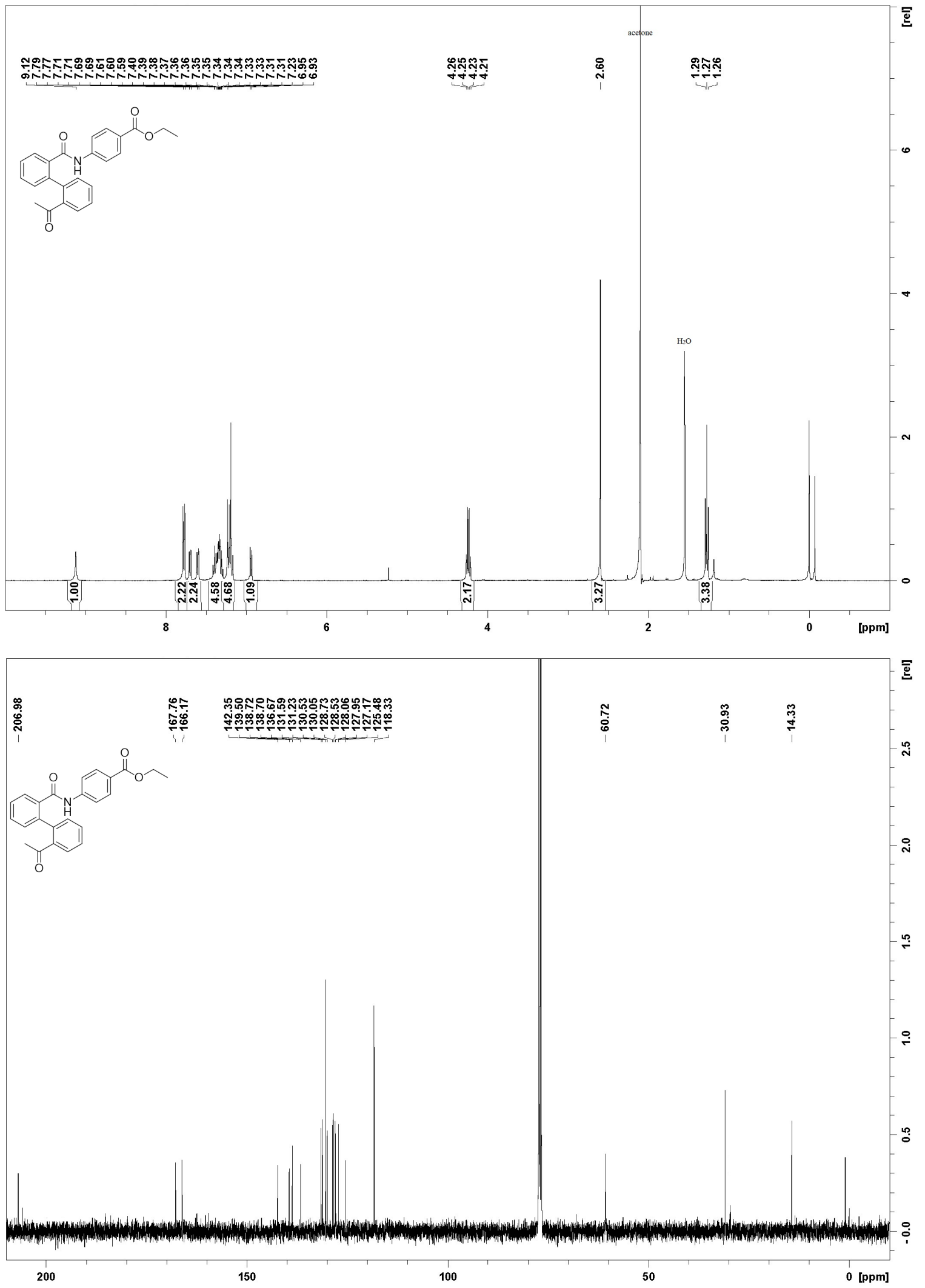


${ }^{1} \mathrm{H}$ and ${ }^{13} \mathrm{C}$ NMR spectra for $\mathbf{1 3}$

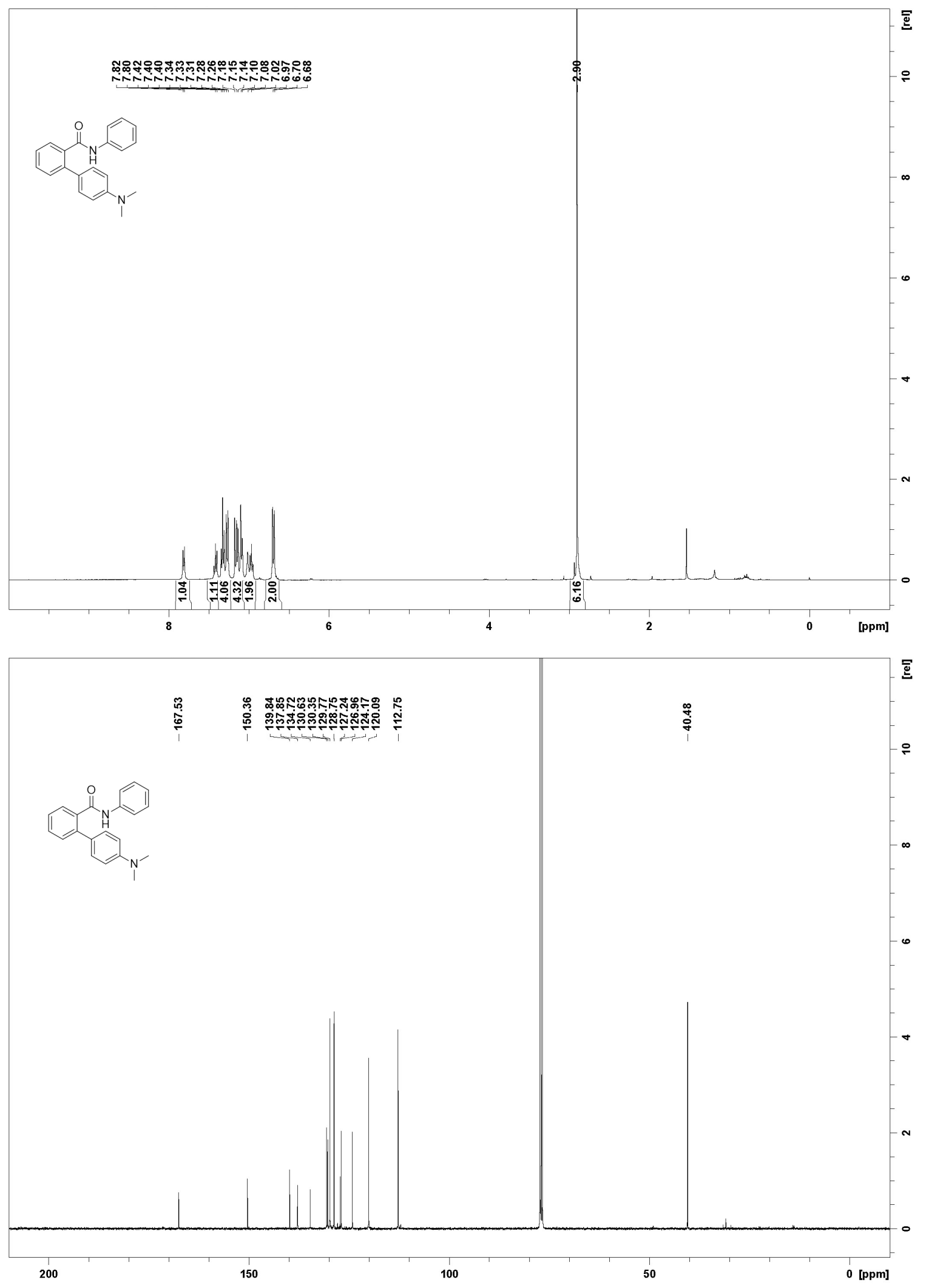


${ }^{1} \mathrm{H}$ and ${ }^{13} \mathrm{C}$ NMR spectra for $\mathbf{1 4}$

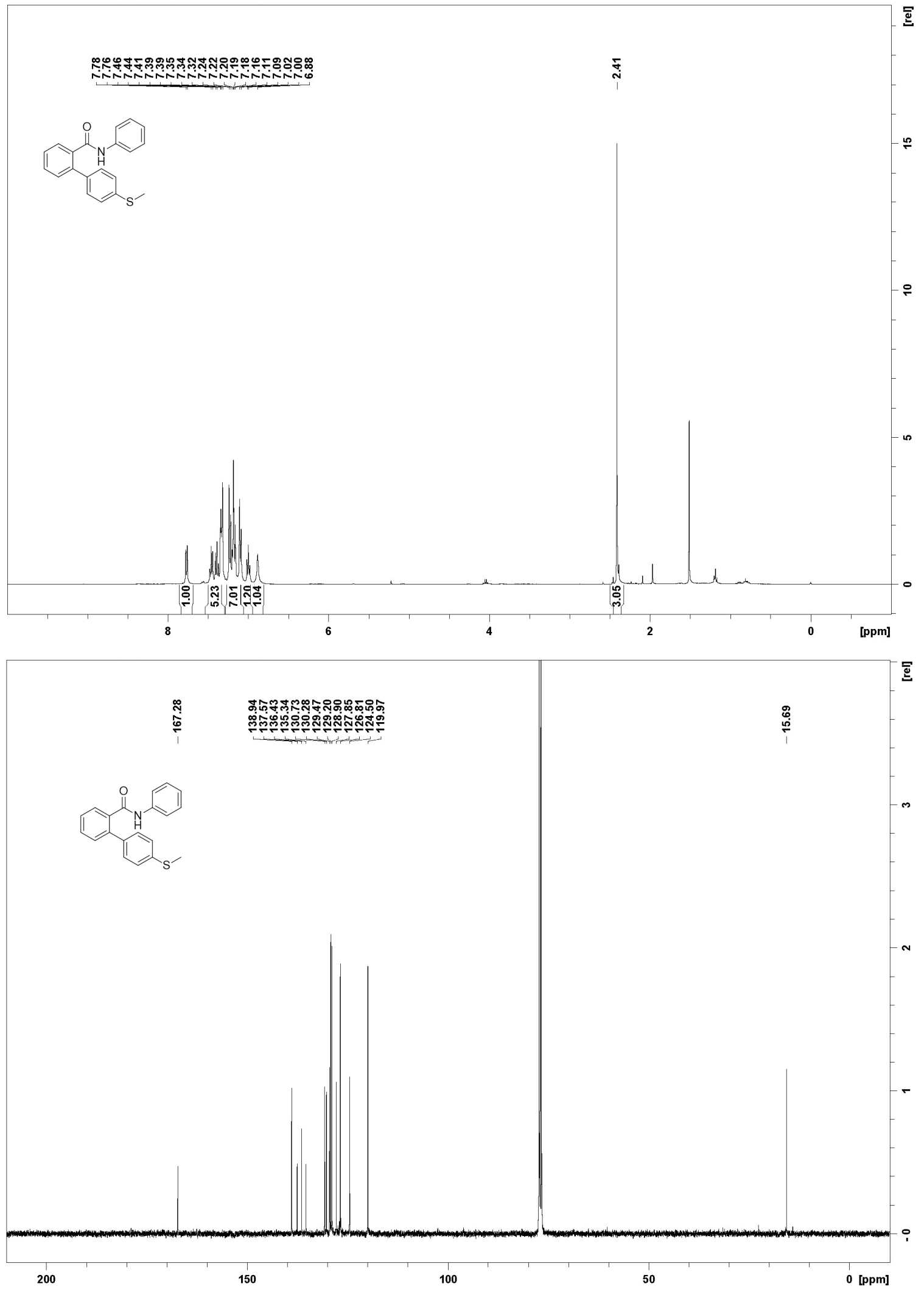


${ }^{1} \mathrm{H}$ and ${ }^{13} \mathrm{C}$ NMR spectra for $\mathbf{1 5}$

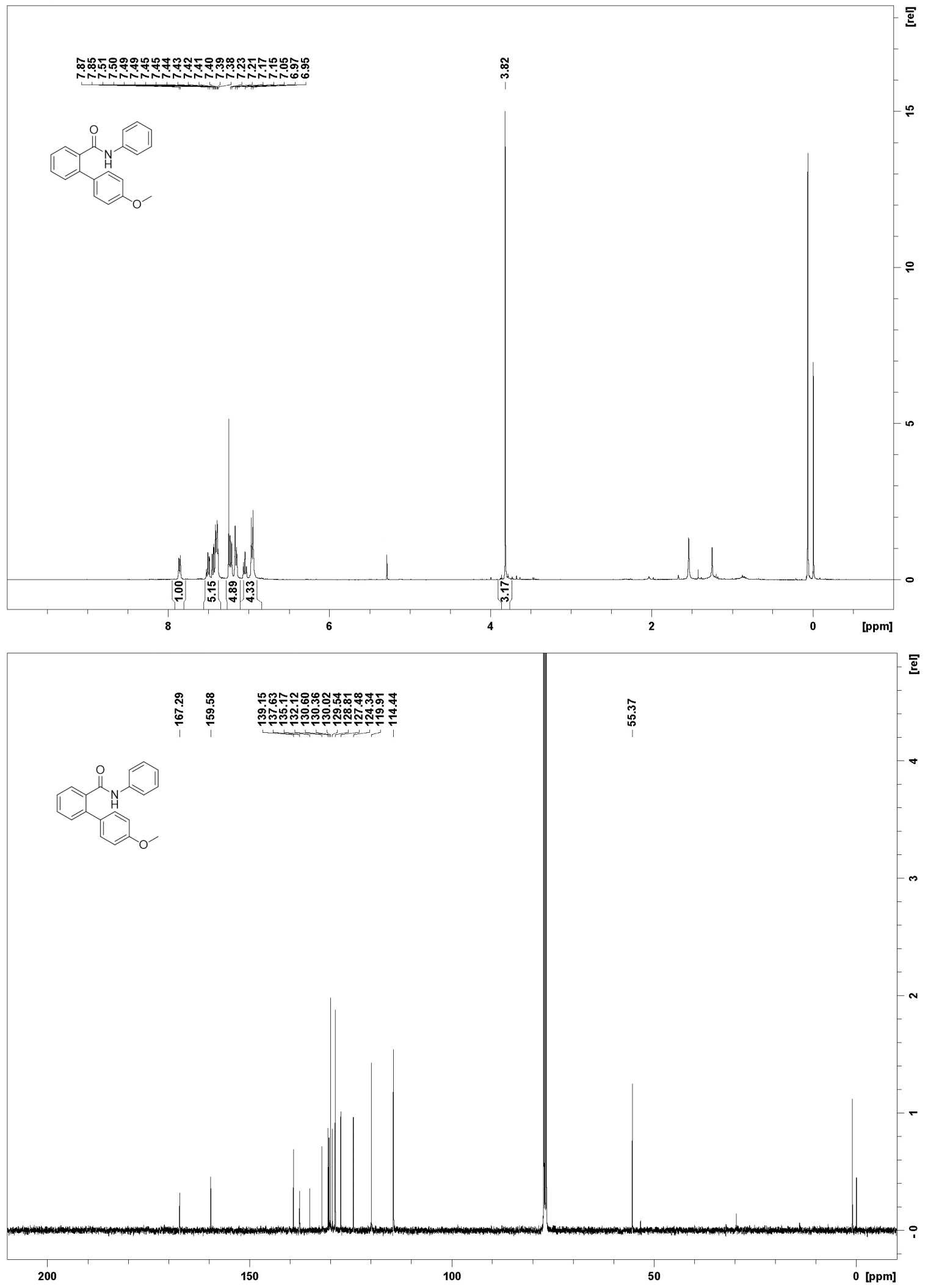


${ }^{1} \mathrm{H}$ and ${ }^{13} \mathrm{C}$ NMR spectra for $\mathbf{1 6}$

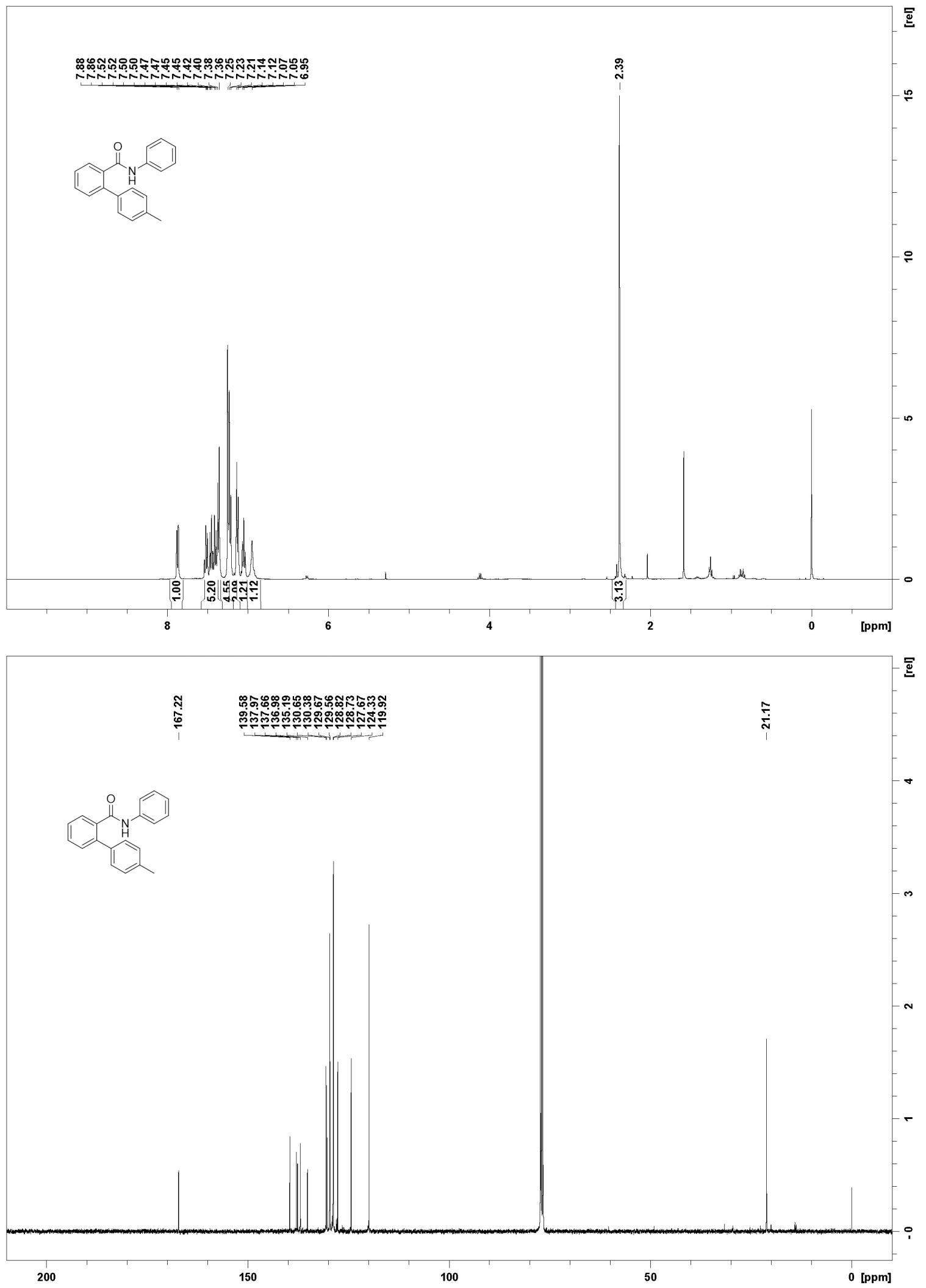


${ }^{1} \mathrm{H}$ and ${ }^{13} \mathrm{C}$ NMR spectra for $\mathbf{1 7}$
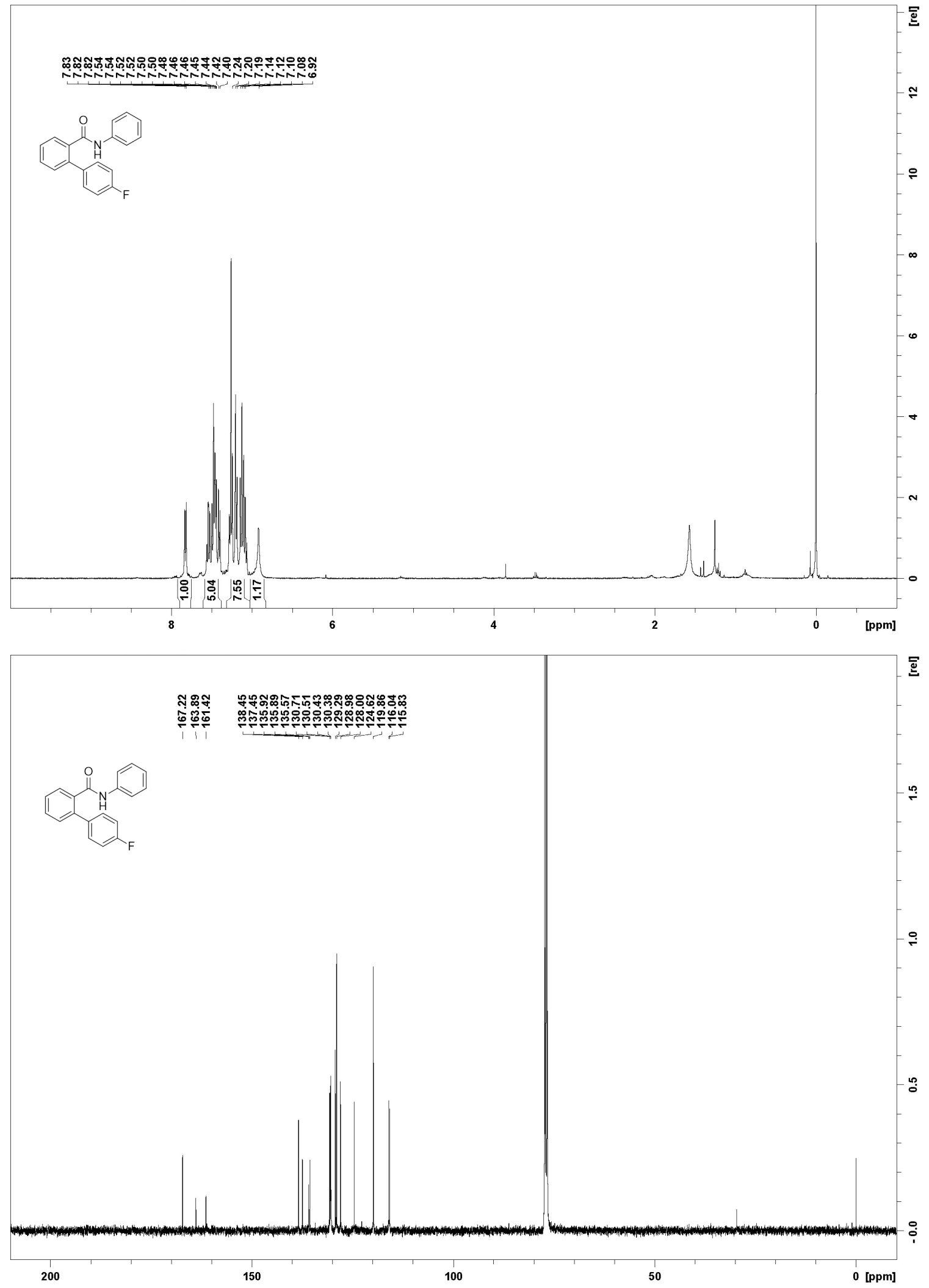
${ }^{1} \mathrm{H}$ and ${ }^{13} \mathrm{C}$ NMR spectra for $\mathbf{1 8}$

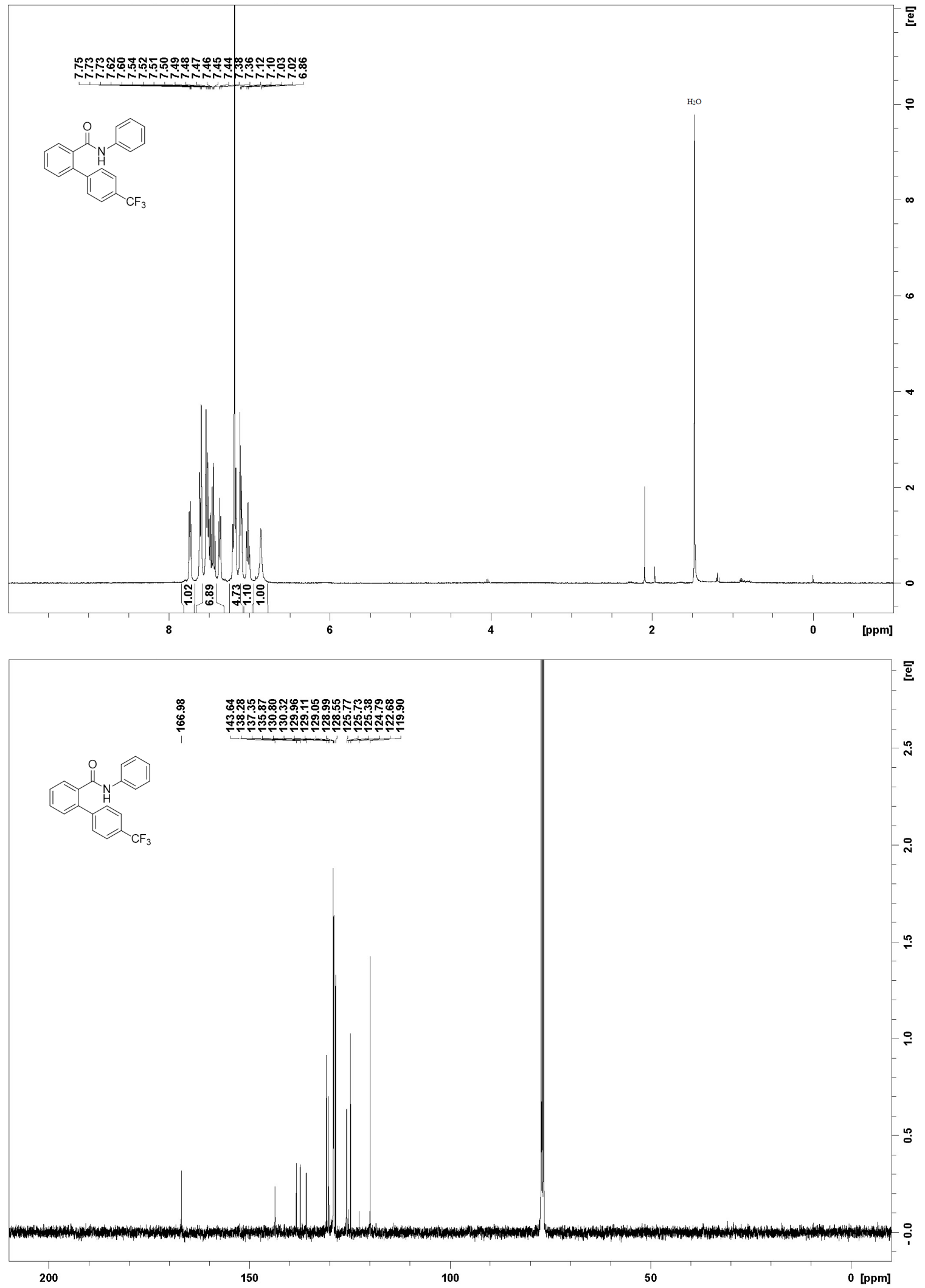


${ }^{1} \mathrm{H}$ and ${ }^{13} \mathrm{C}$ NMR spectra for 19

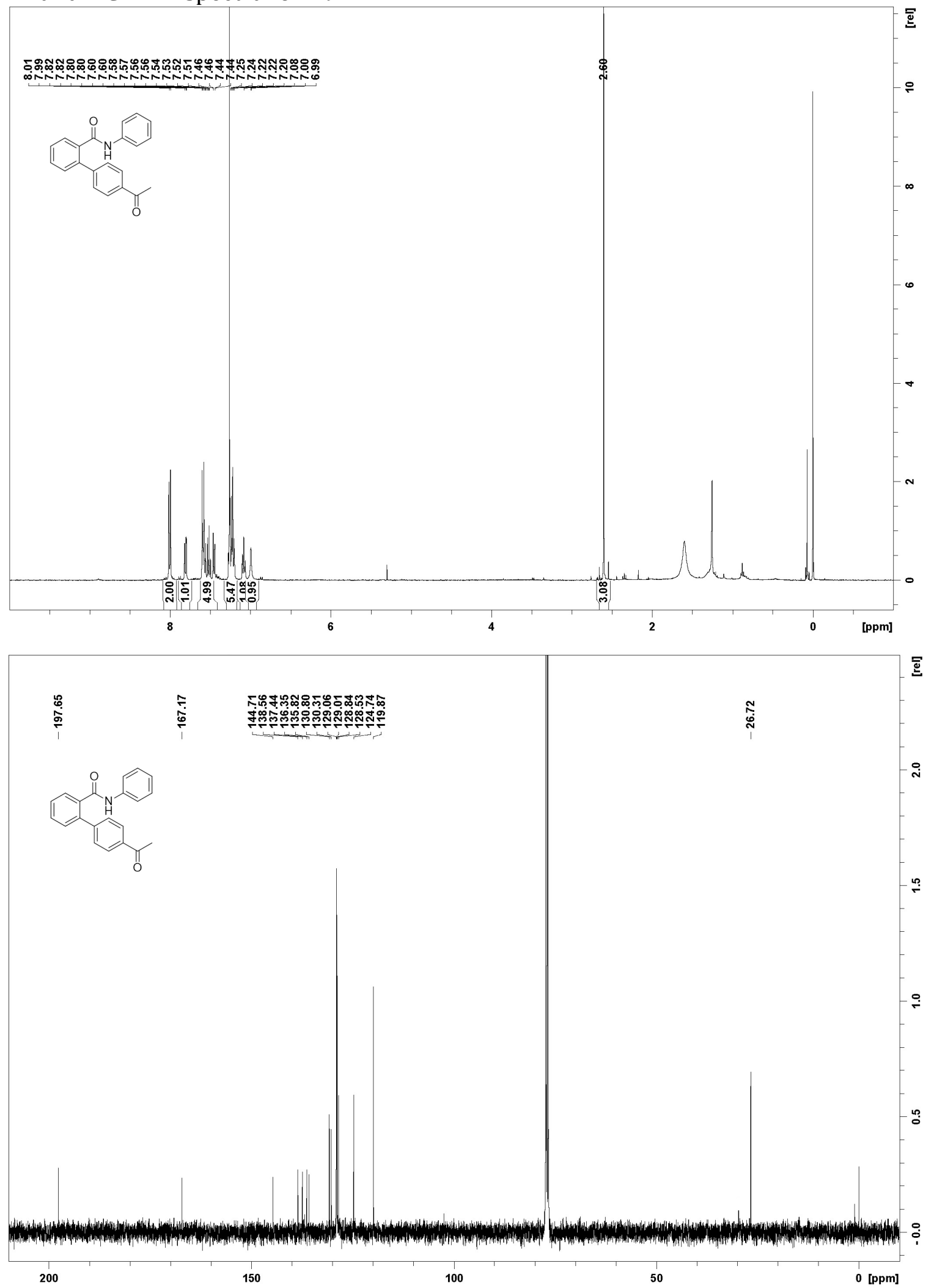


${ }^{1} \mathrm{H}$ and ${ }^{13} \mathrm{C}$ NMR spectra for $\mathbf{2 0}$

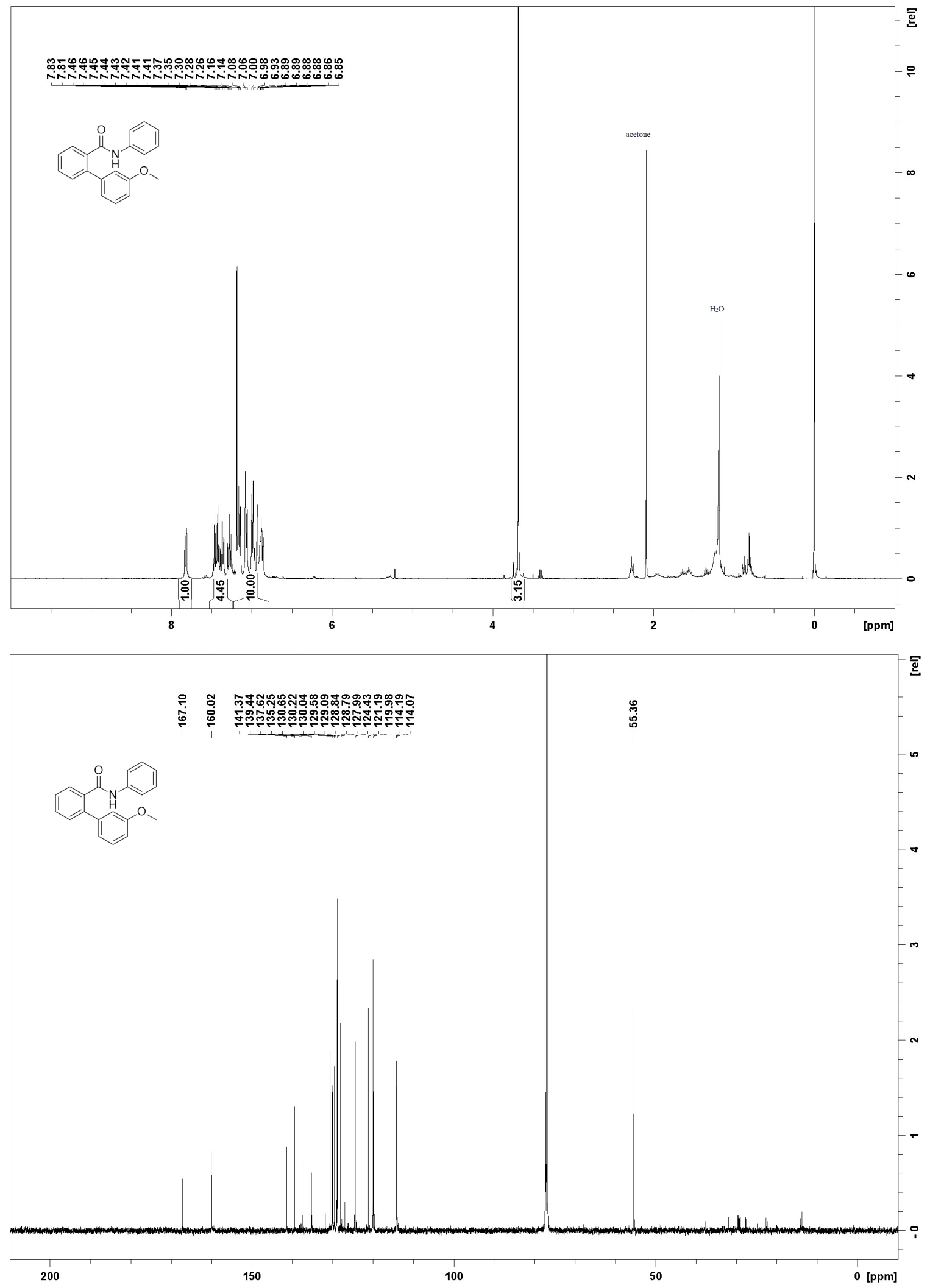


${ }^{1} \mathrm{H}$ and ${ }^{13} \mathrm{C}$ NMR spectra for $\mathbf{2 1}$

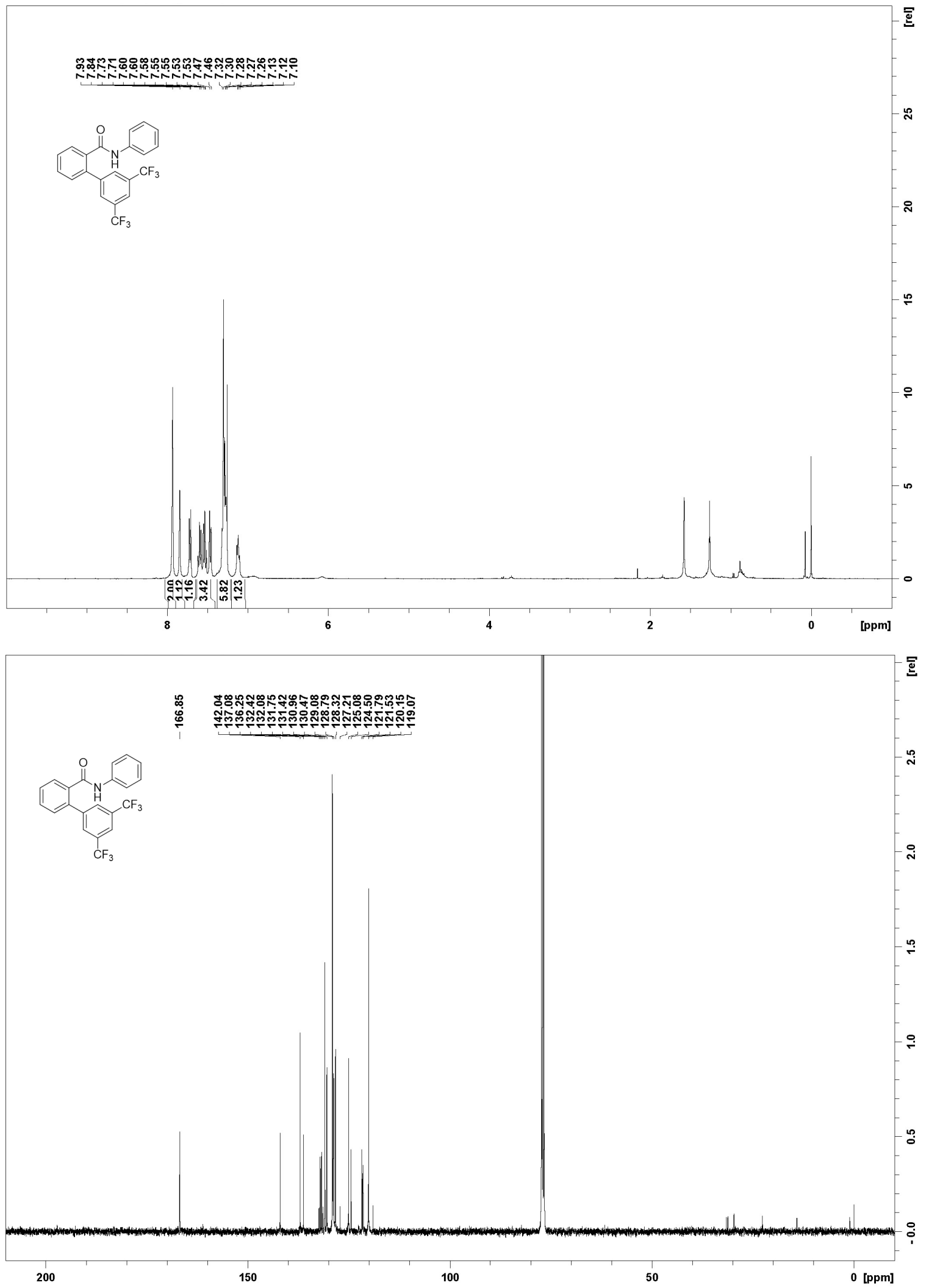


${ }^{1} \mathrm{H}$ and ${ }^{13} \mathrm{C}$ NMR spectra for $\mathbf{2 2}$
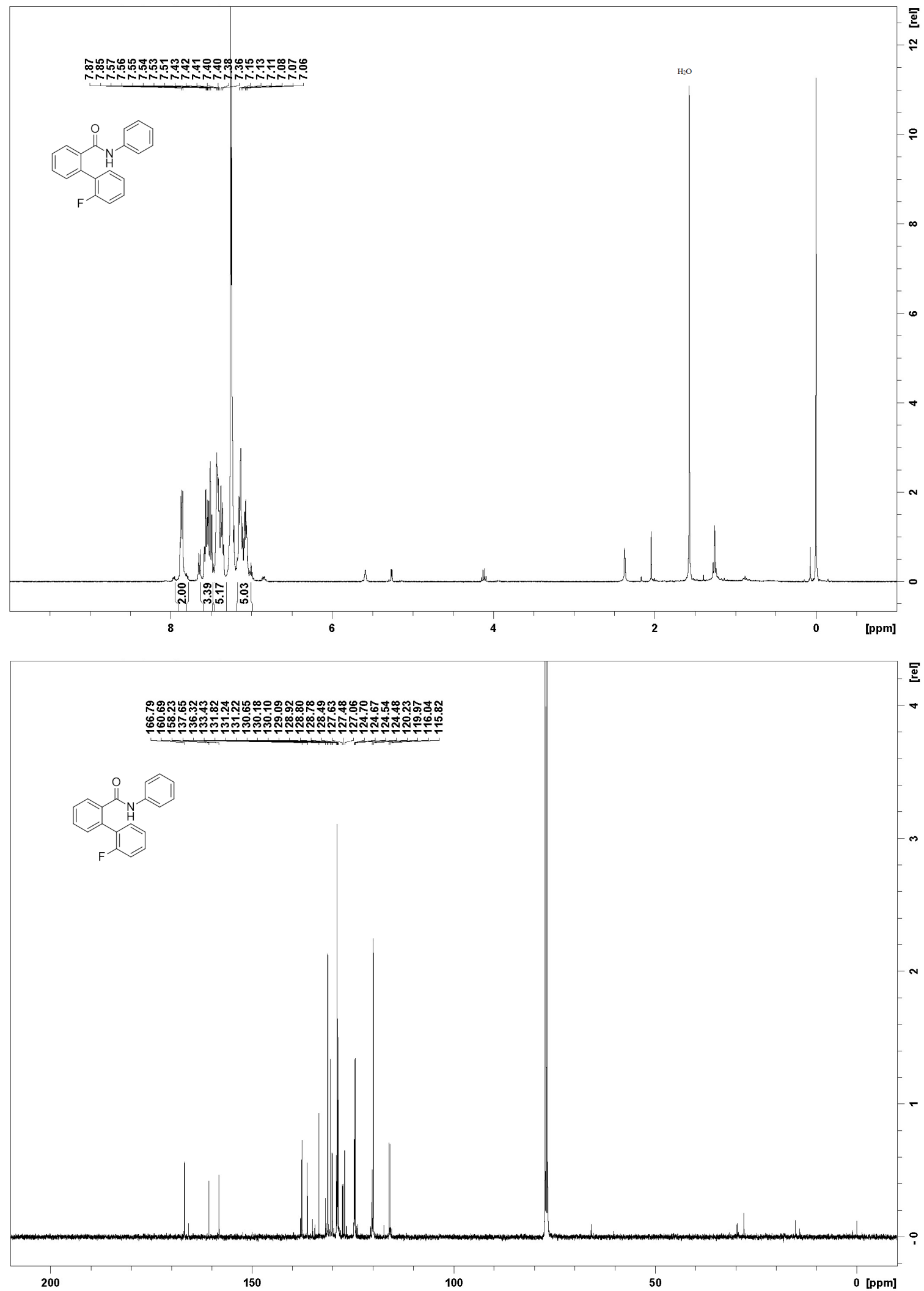
${ }^{1} \mathrm{H}$ and ${ }^{13} \mathrm{C}$ NMR spectra for $\mathbf{2 3}$

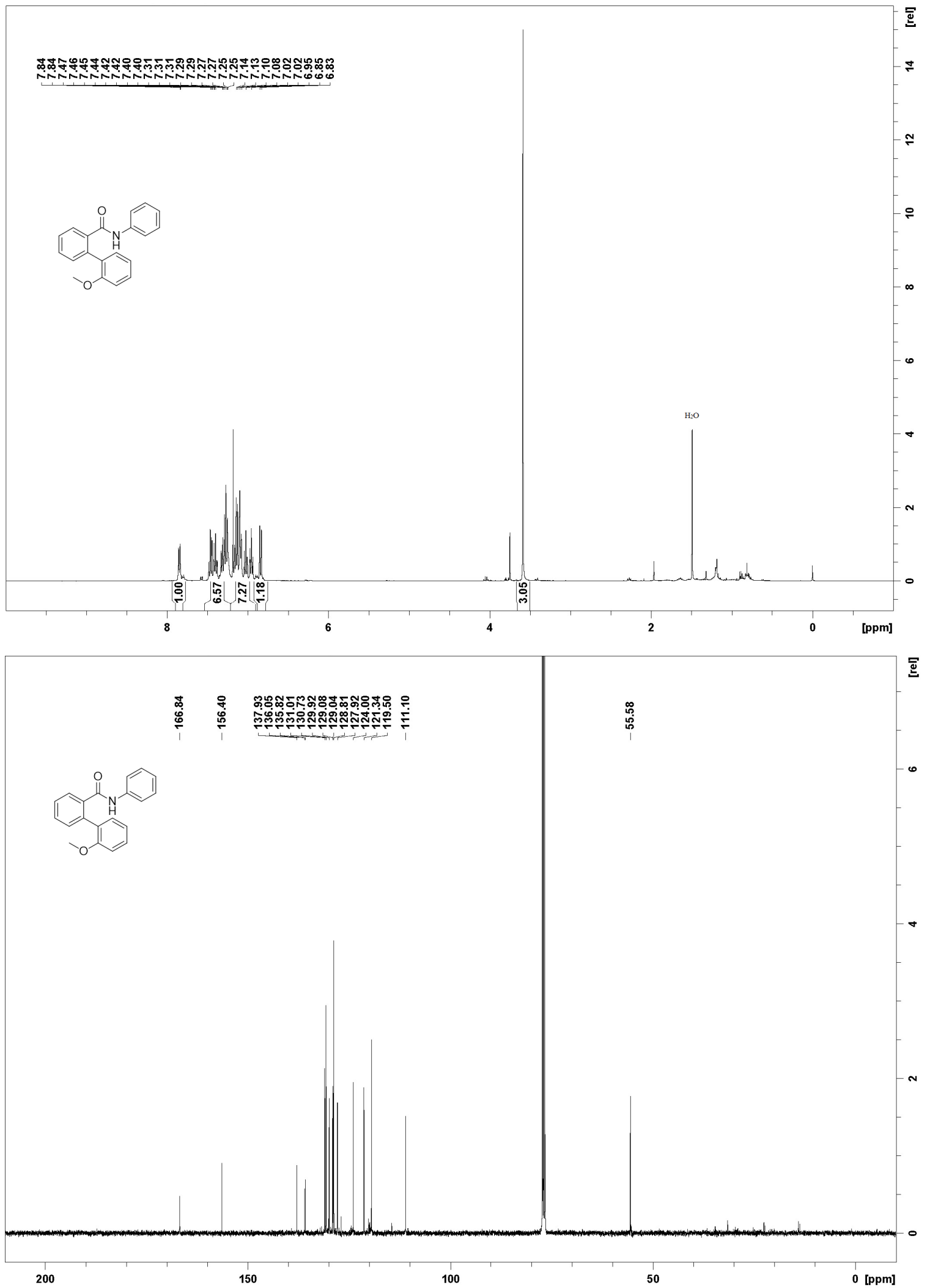


${ }^{1} \mathrm{H}$ and ${ }^{13} \mathrm{C}$ NMR spectra for $\mathbf{2 4}$

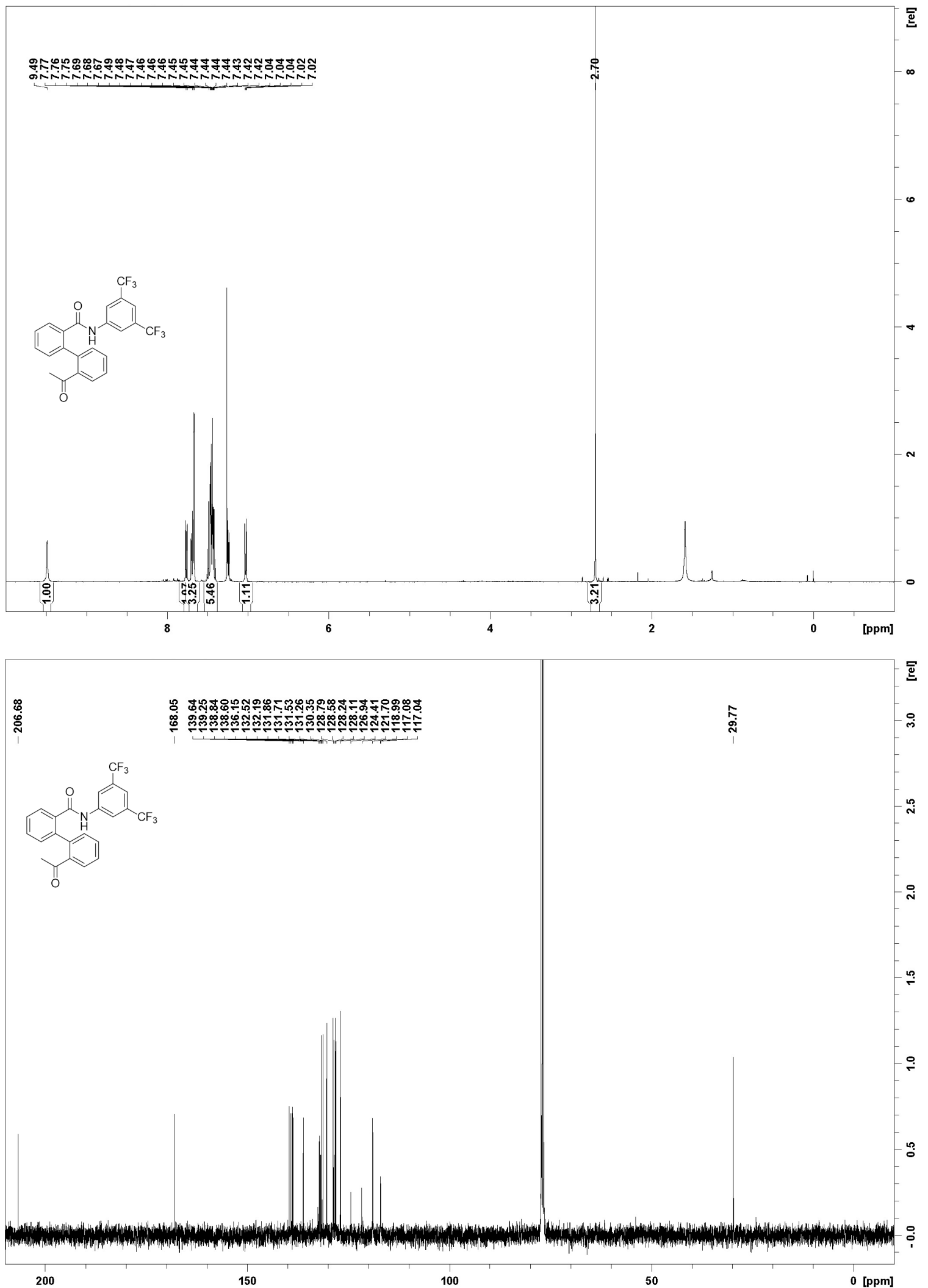


${ }^{1} \mathrm{H}$ and ${ }^{13} \mathrm{C}$ NMR spectra for $\mathbf{2 5}$

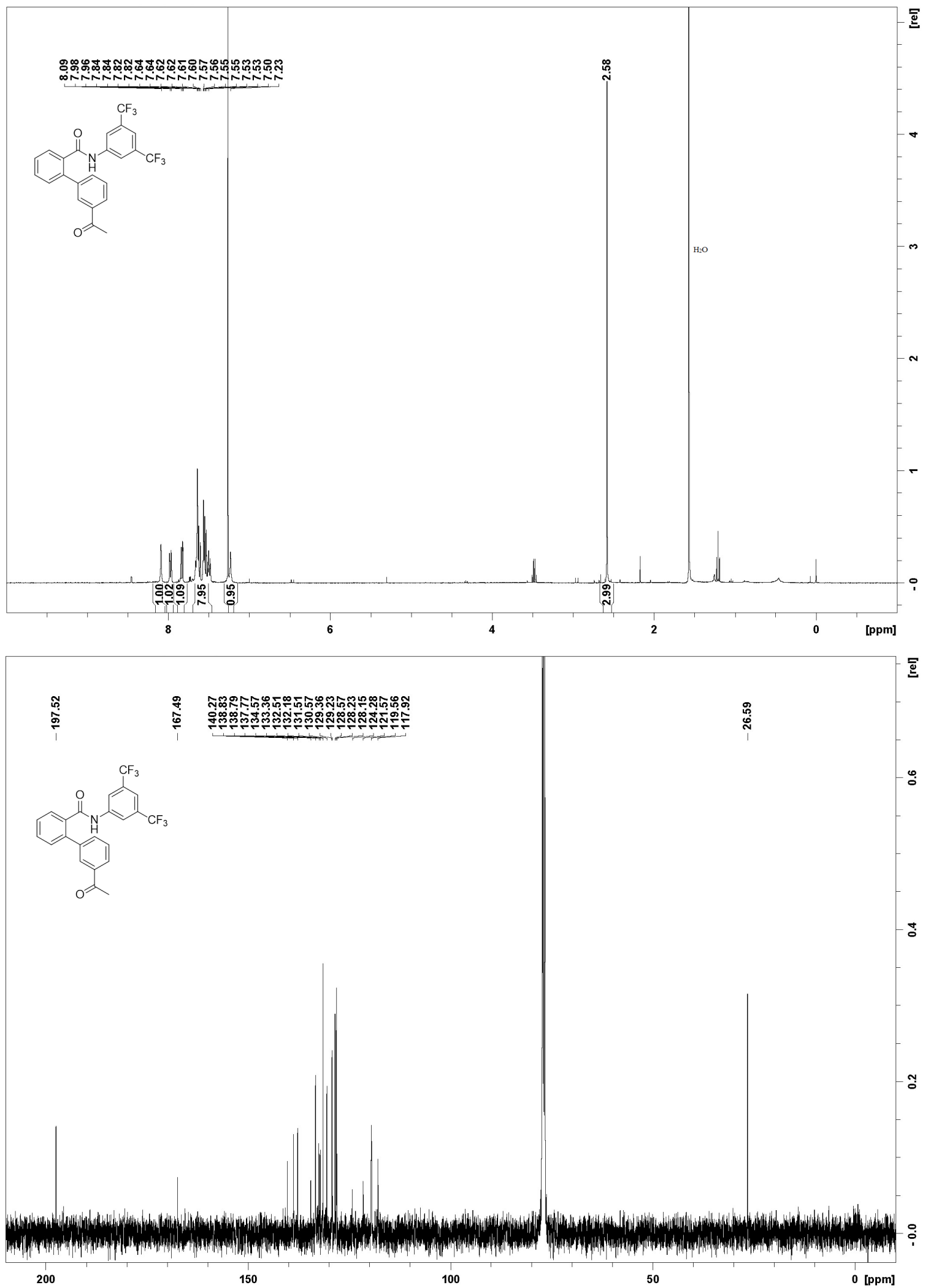


${ }^{1} \mathrm{H}$ and ${ }^{13} \mathrm{C}$ NMR spectra for $\mathbf{2 6}$

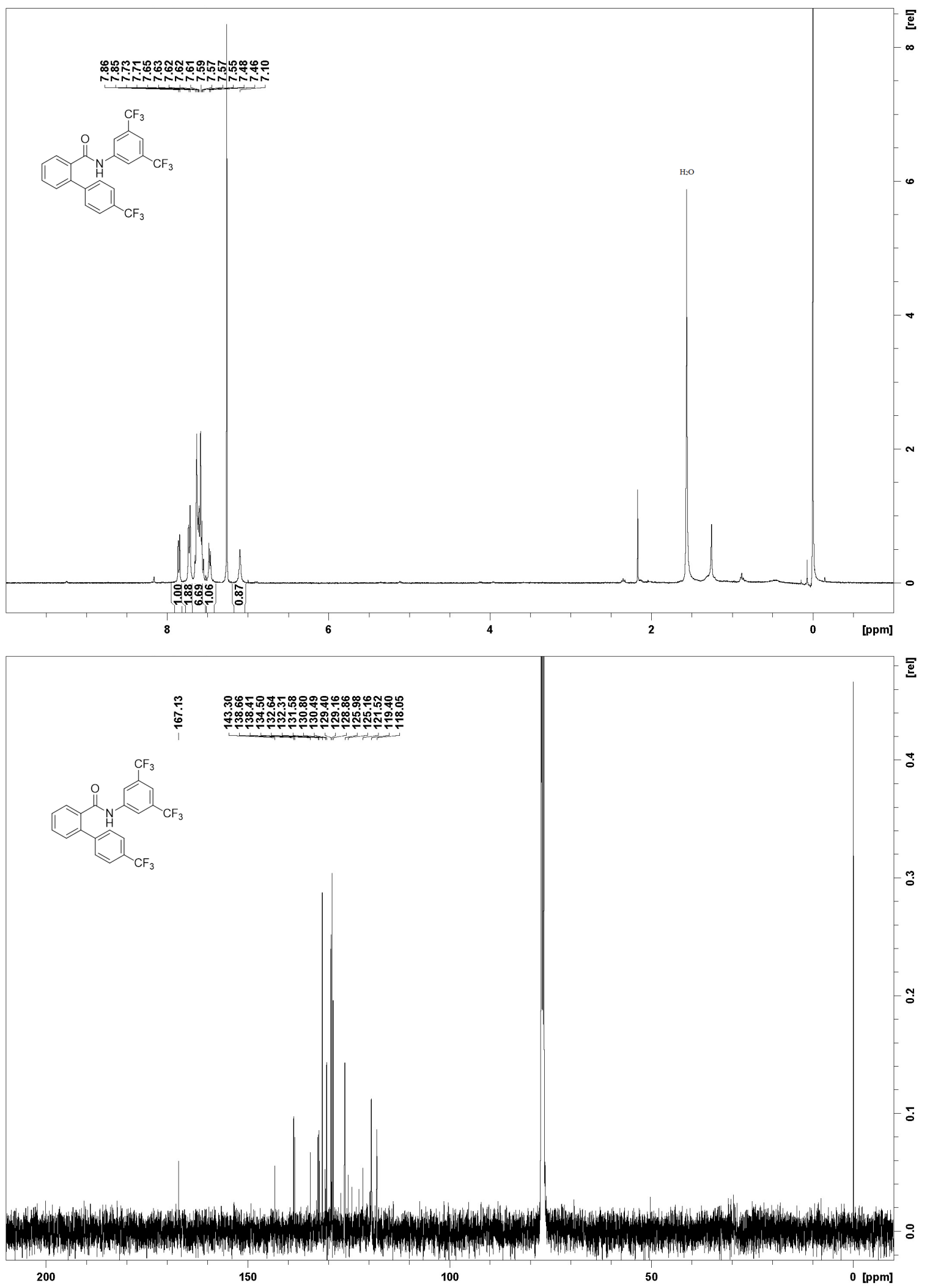


${ }^{1} \mathrm{H}$ and ${ }^{13} \mathrm{C}$ NMR spectra for $\mathbf{2 7}$

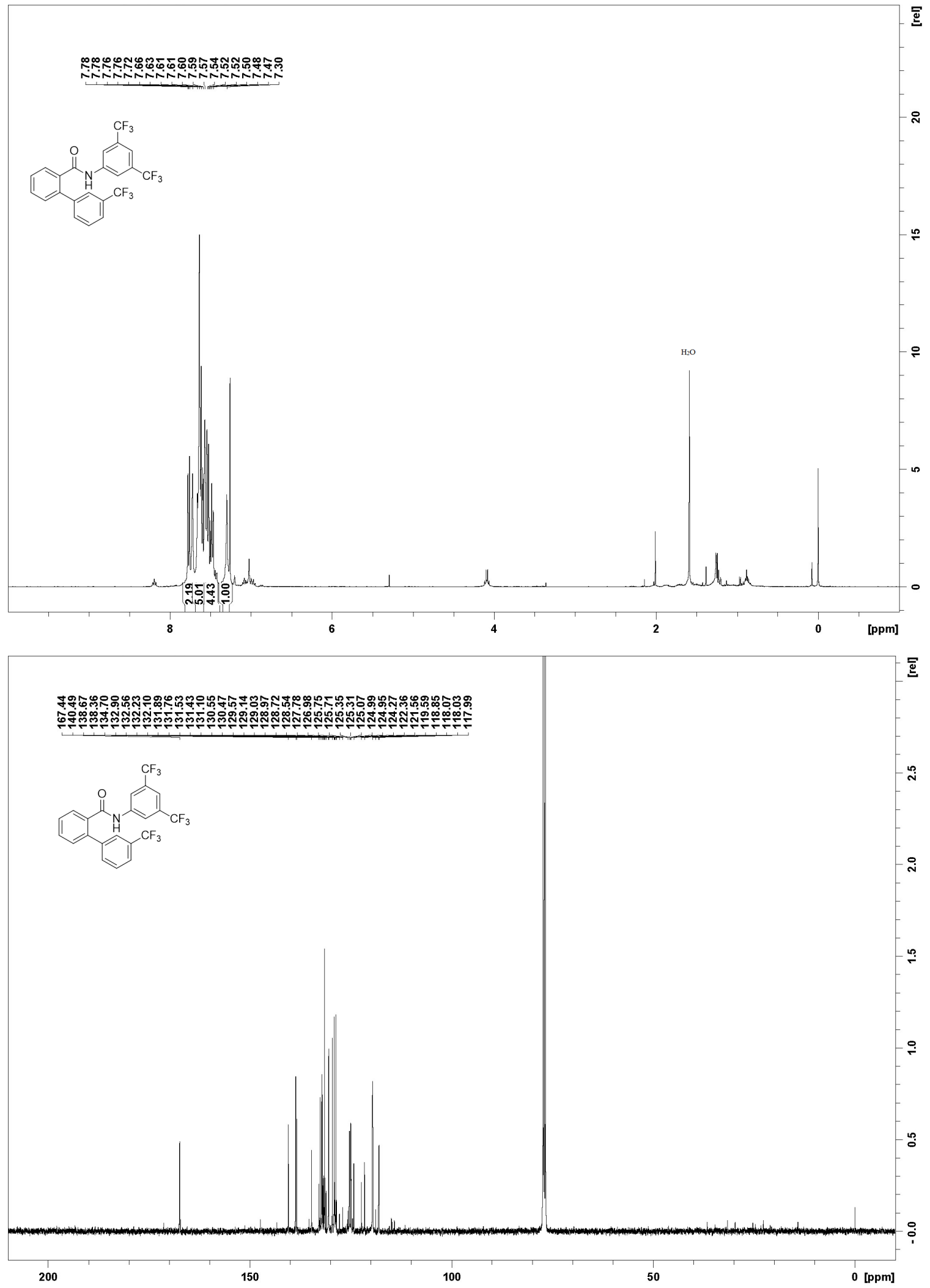


${ }^{1} \mathrm{H}$ and ${ }^{13} \mathrm{C}$ NMR spectra for $\mathbf{2 8}$

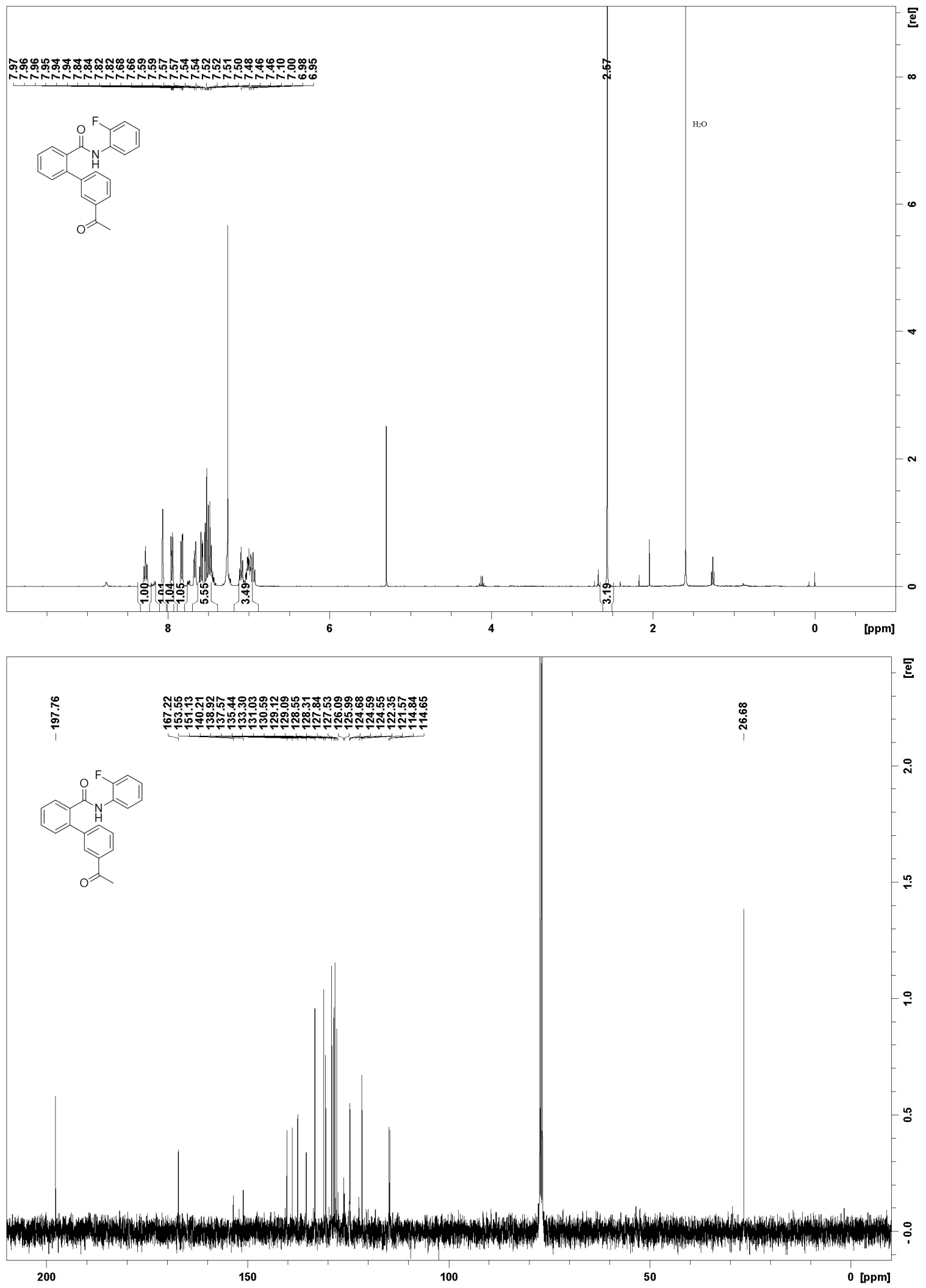


${ }^{1} \mathrm{H}$ and ${ }^{13} \mathrm{C}$ NMR spectra for $\mathbf{2 9}$

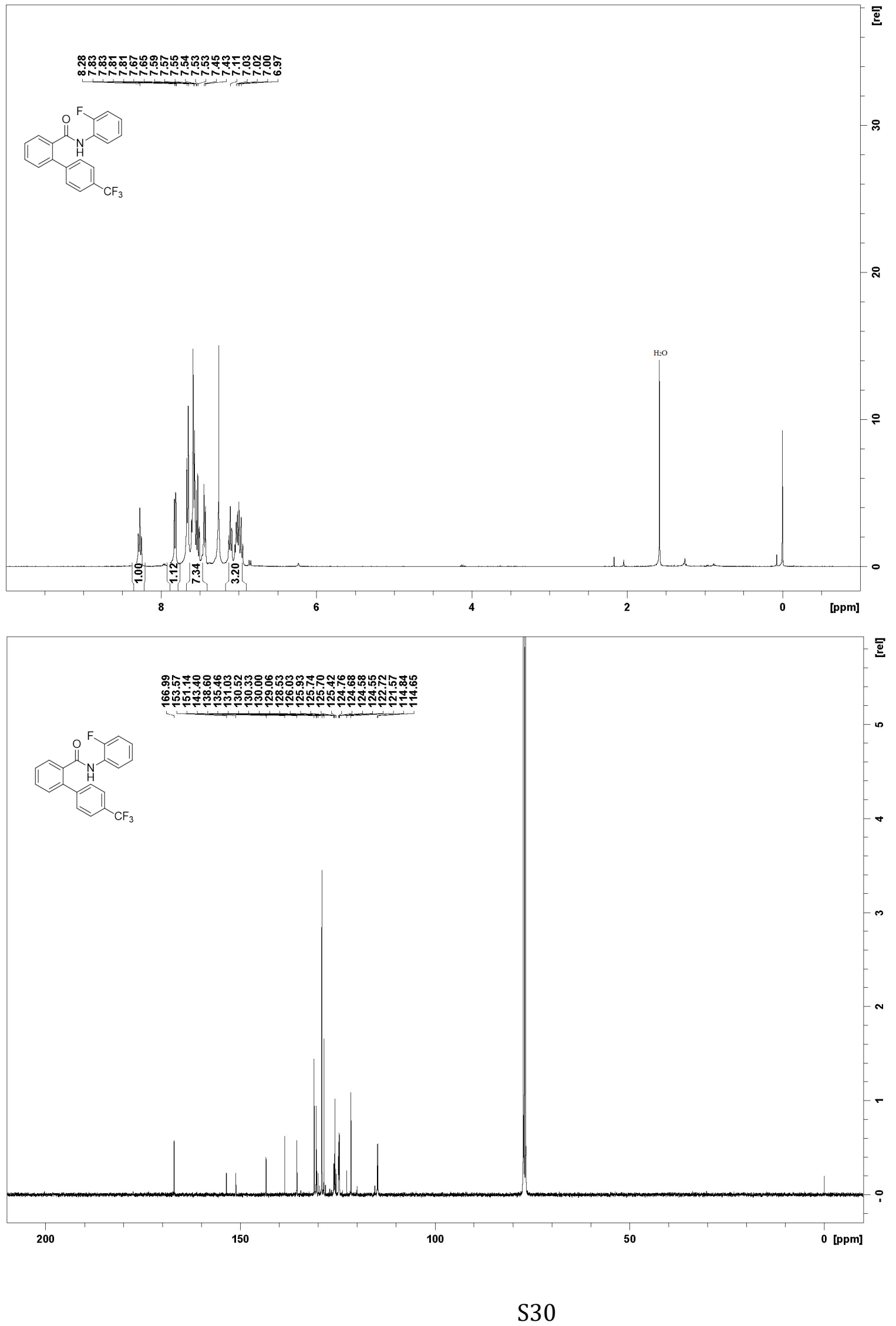


${ }^{1} \mathrm{H}$ and ${ }^{13} \mathrm{C}$ NMR spectra for $\mathbf{3 0}$

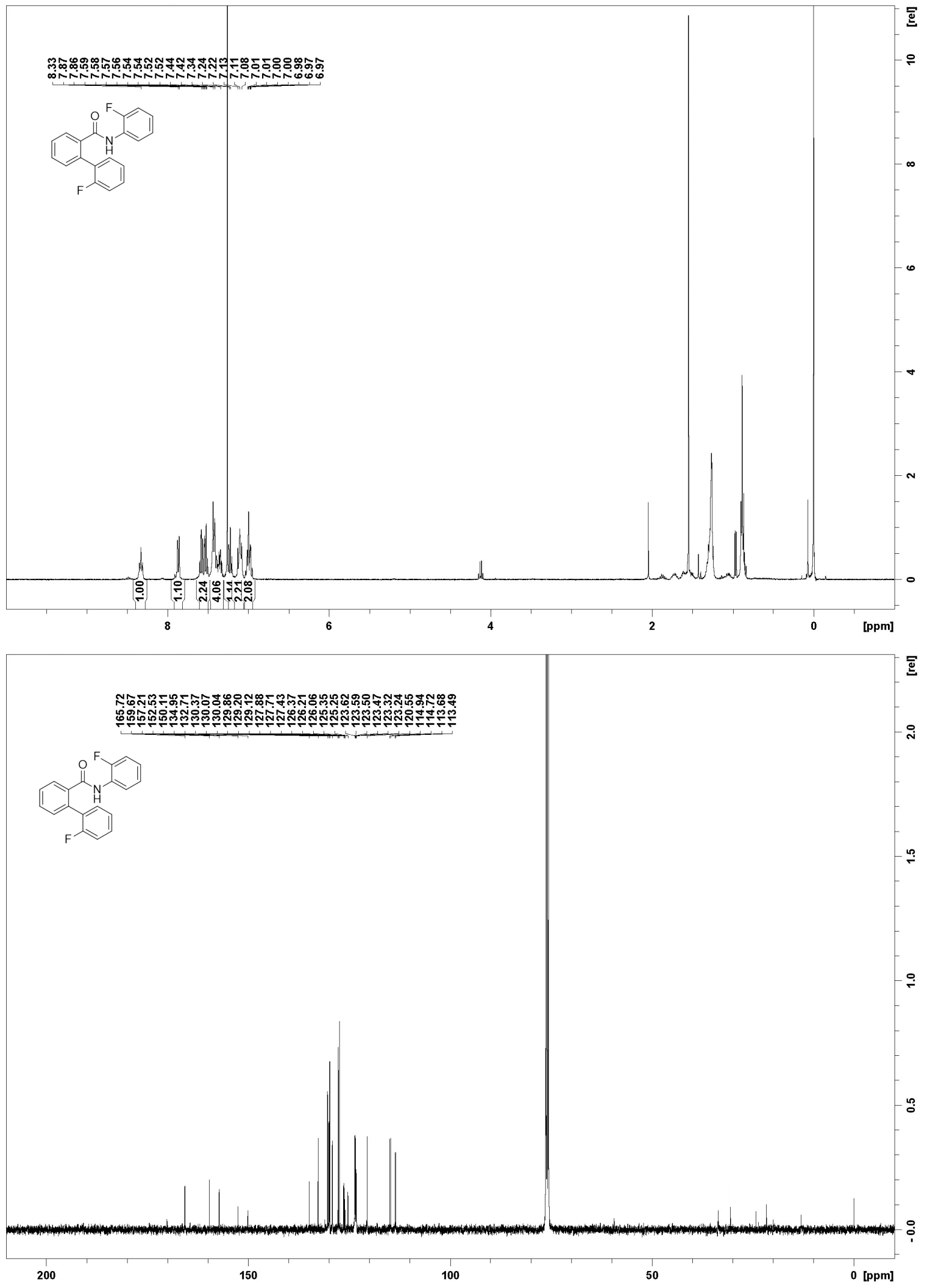


${ }^{1} \mathrm{H}$ and ${ }^{13} \mathrm{C}$ NMR spectra for $\mathbf{3 1}$

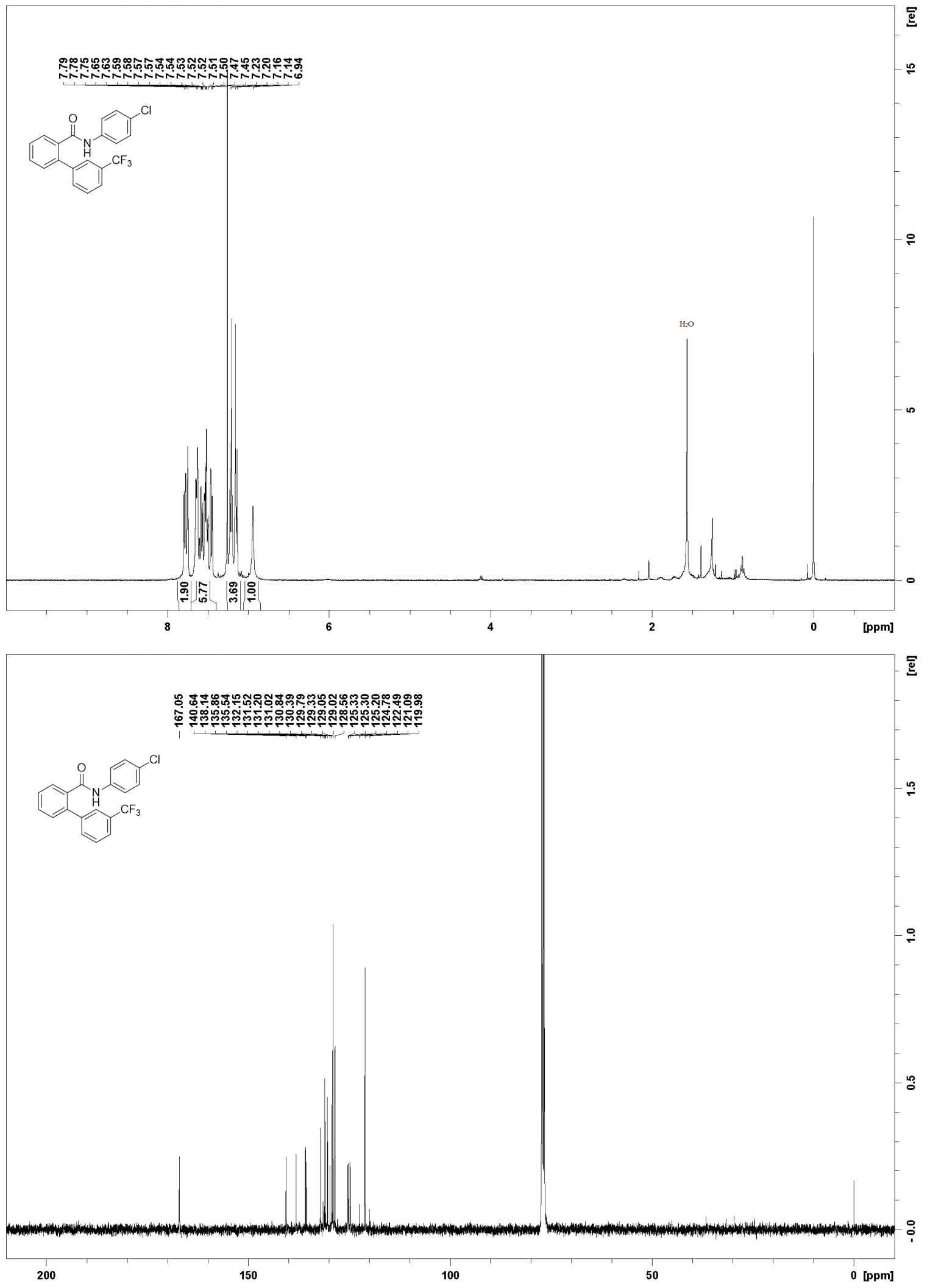


${ }^{1} \mathrm{H}$ and ${ }^{13} \mathrm{C}$ NMR spectra for 32

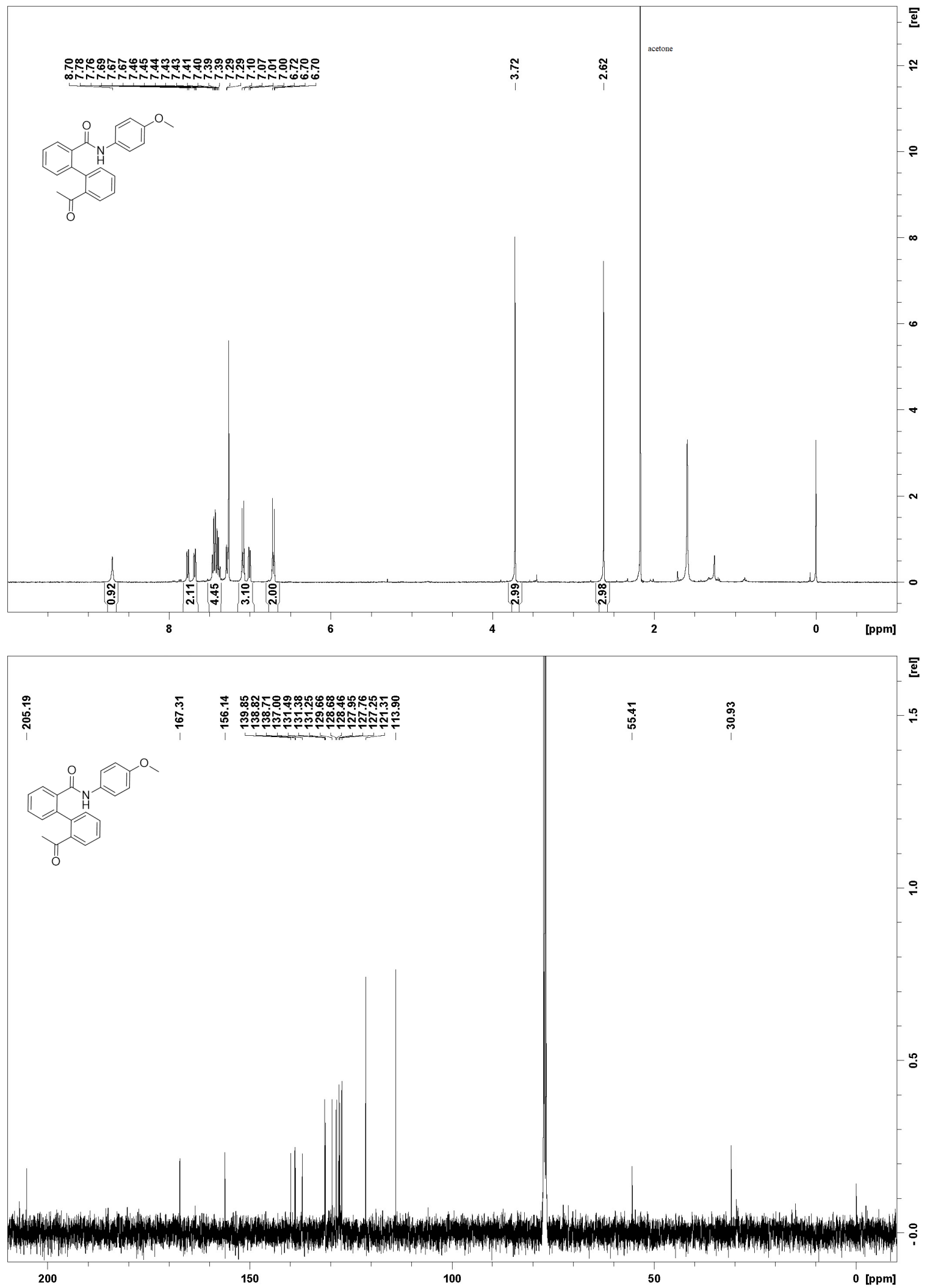


${ }^{1} \mathrm{H}$ and ${ }^{13} \mathrm{C}$ NMR spectra for $\mathbf{3 3}$

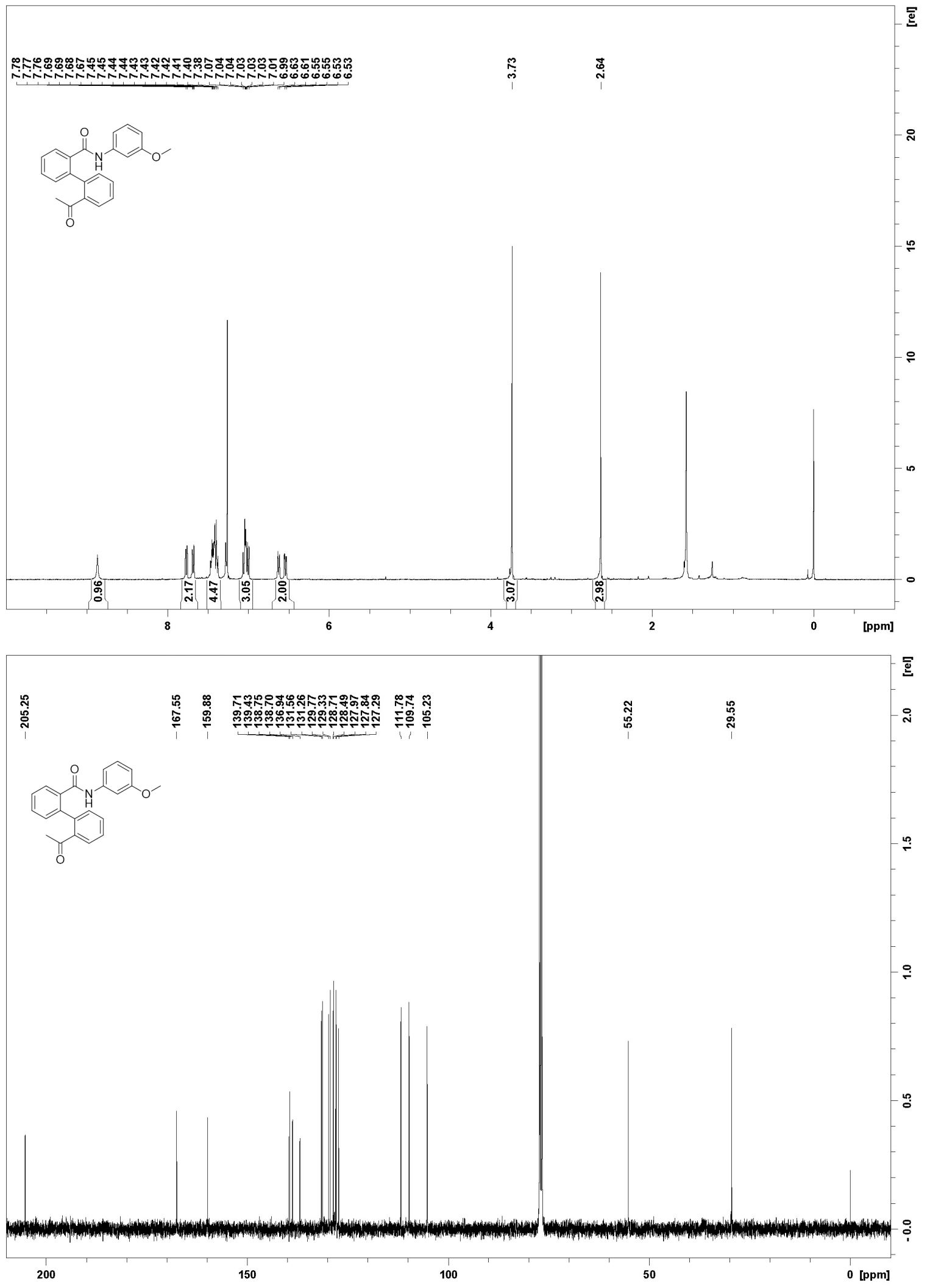


${ }^{1} \mathrm{H}$ and ${ }^{13} \mathrm{C}$ NMR spectra for $\mathbf{3 4}$

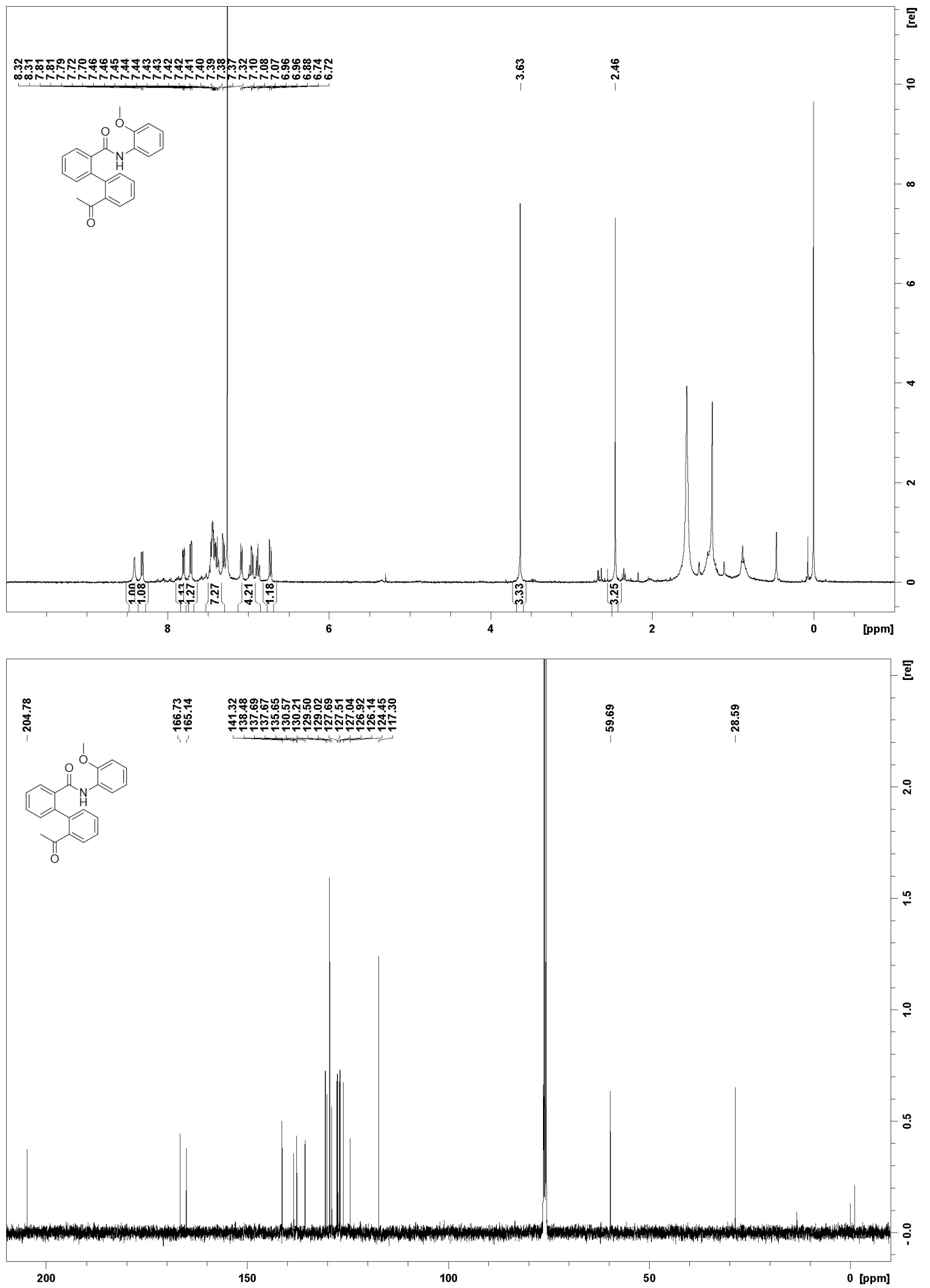


${ }^{1} \mathrm{H}$ and ${ }^{13} \mathrm{C}$ NMR spectra for $\mathbf{3 5}$

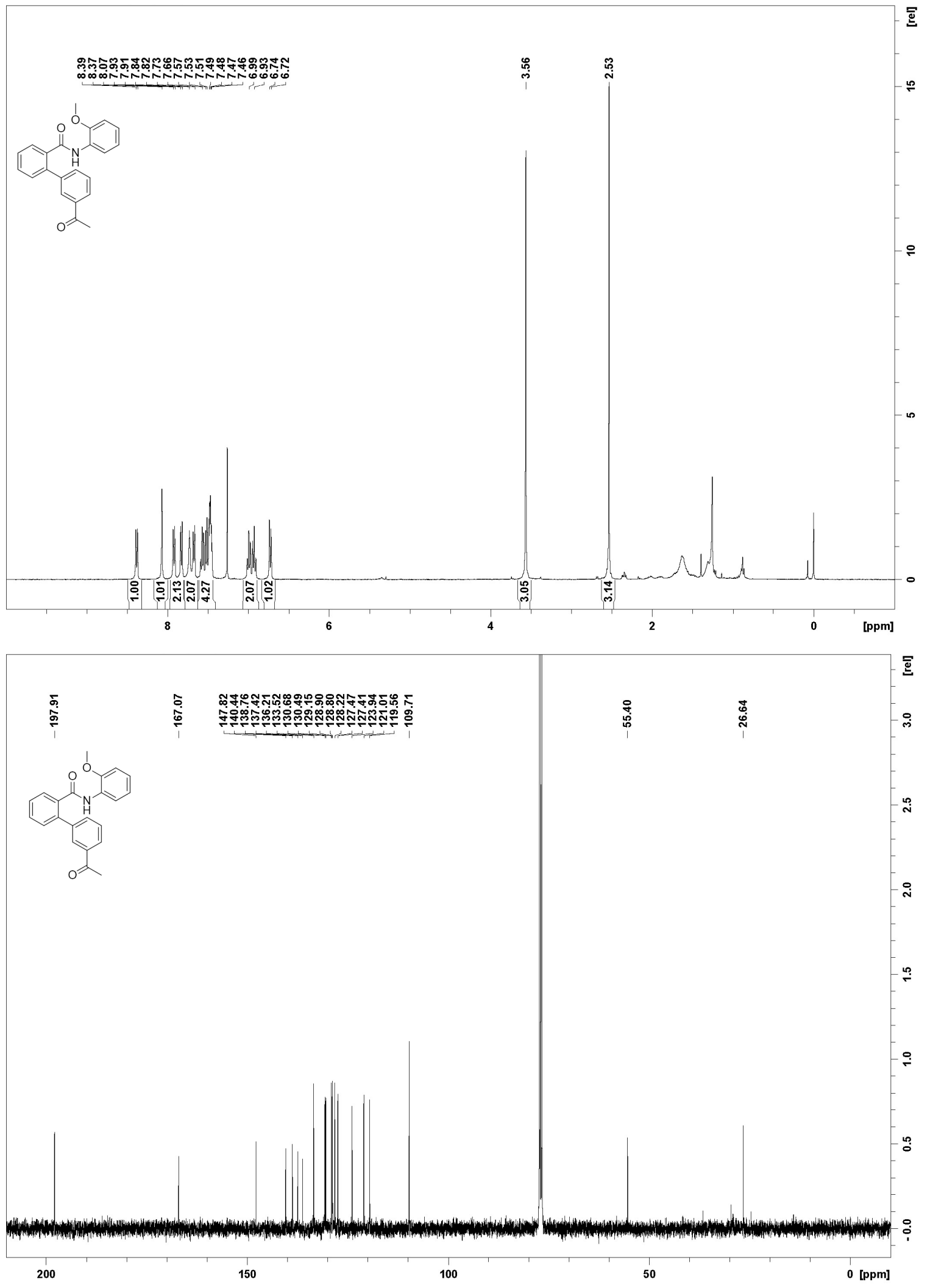


${ }^{1} \mathrm{H}$ and ${ }^{13} \mathrm{C}$ NMR spectra for 36

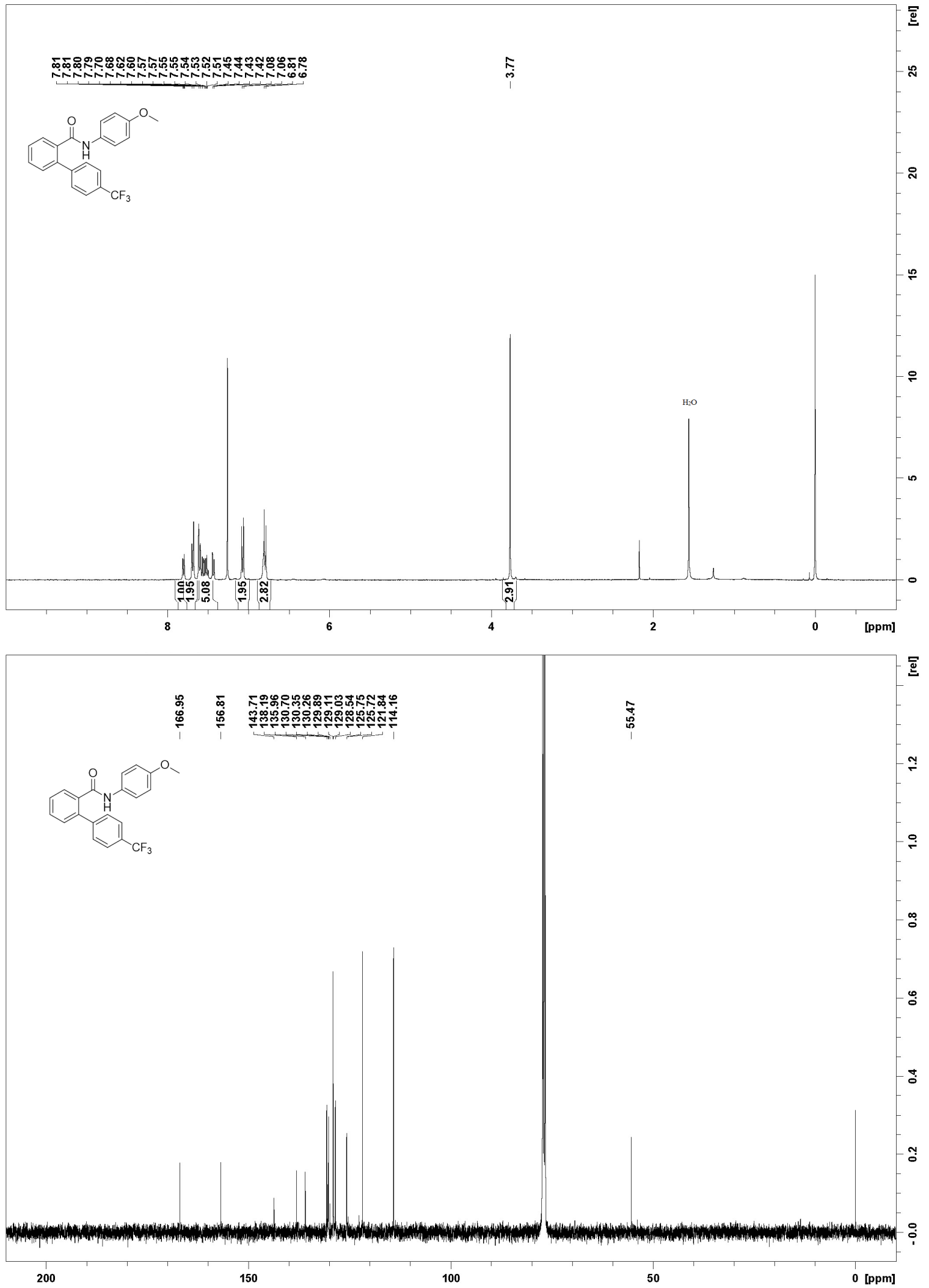

